\title{
Salt-inducible kinases (SIKs) regulate TGF $\beta$-mediated transcriptional and apoptotic responses
}

\author{
Luke D. Hutchinson ${ }^{1,3}$, Nicola J. Darling ${ }^{1}$, Stephanos Nicolaou ${ }^{2,4}$, llaria Gori ${ }^{2}$, Daniel R. Squair ${ }^{1}$, Philip Cohen ${ }^{1}$, \\ Caroline S. Hill ${ }^{2}$ and Gopal P. Sapkota (10)
}

\begin{abstract}
The signalling pathways initiated by members of the transforming growth factor- $\beta$ (TGF $\beta$ ) family of cytokines control many metazoan cellular processes, including proliferation and differentiation, epithelial-mesenchymal transition (EMT) and apoptosis. TGF $\beta$ signalling is therefore strictly regulated to ensure appropriate context-dependent physiological responses. In an attempt to identify novel regulatory components of the TGF $\beta$ signalling pathway, we performed a pharmacological screen by using a cell line engineered to report the endogenous transcription of the TGF $\beta$-responsive target gene PAl-1. The screen revealed that small molecule inhibitors of salt-inducible kinases (SIKs) attenuate TGF $\beta$-mediated transcription of PAI-1 without affecting receptor-mediated SMAD phosphorylation, SMAD complex formation or nuclear translocation. We provide evidence that genetic inactivation of SIK isoforms also attenuates TGF $\beta$-dependent transcriptional responses. Pharmacological inhibition of SIKs by using multiple small-molecule inhibitors potentiated apoptotic cell death induced by TGF $\beta$ stimulation. Our data therefore provide evidence for a novel function of SIKs in modulating TGF $\beta$-mediated transcriptional and cellular responses.
\end{abstract}

\section{Introduction}

Signalling pathways initiated by the TGF $\beta$ family of cytokines are amongst the most prevalent and diverse in metazoan biology, and regulate a multitude of processes, including cellular proliferation and differentiation, epithelial-mesenchymal transition (EMT), cell migration, immunoregulation and apoptotic cell death in a contextdependent manner ${ }^{1-6}$. Consequently, perturbations within the signalling pathway have been associated with the pathogenesis of many human disorders including cancer. For example, in normal epithelial cells, TGF $\beta$ has a tumour-suppressive function, principally through its ability to induce cytostasis and apoptotic cell death ${ }^{7-9}$. In

Correspondence: Gopal P. Sapkota (g.sapkota@dundee.ac.uk)

${ }^{1}$ MRC Protein Phosphorylation and Ubiquitylation Unit, School of Life Sciences, University of Dundee, Sir James Black Centre, Dow Street, Dundee DD1 5EH, UK ${ }^{2}$ The Francis Crick Institute, 1 Midland Road, London NW1 1AT, UK Full list of author information is available at the end of the article. Edited by I. Amelio contrast, during tumour progression, the suppressive effect of TGF $\beta$ is lost, and in certain cancers, corruption of the signalling pathway can result in TGF $\beta$ exerting a pro-oncogenic effect ${ }^{7,10,11}$. Inhibition of the TGF $\beta$ pathway has therefore been proposed as a potential therapeutic strategy in certain pathological contexts ${ }^{12,13}$. However, the highly pleiotropic and context-dependent nature of TGF $\beta$ signalling has provided a considerable challenge for pharmacological intervention ${ }^{14}$. Elucidating the context-dependent regulatory mechanisms underlying TGF $\beta$ signalling is therefore of considerable importance in identifying novel therapeutic interventions.

TGF $\beta$ signalling is initiated upon the binding of TGF $\beta$ ligand dimers to cognate transmembrane receptor serine-threonine protein kinases to form activated heterotetrameric receptor complexes containing two type I and two type II receptors ${ }^{15}$. This allows the constitutively active type II receptor to phosphorylate multiple serine and threonine residues within the cytoplasmic domain of

\section{(c) The Author(s) 2020}

(c) (i) Open Access This article is licensed under a Creative Commons Attribution 4.0 International License, which permits use, sharing, adaptation, distribution and reproduction cc) in any medium or format, as long as you give appropriate credit to the original author(s) and the source, provide a link to the Creative Commons license, and indicate if changes were made. The images or other third party material in this article are included in the article's Creative Commons license, unless indicated otherwise in a credit line to the material. If material is not included in the article's Creative Commons license and your intended use is not permitted by statutory regulation or exceeds the permitted use, you will need to obtain permission directly from the copyright holder. To view a copy of this license, visit http://creativecommons.org/licenses/by/4.0/. 
the type I receptor, which enables the type I receptor to bind and phosphorylate the SMAD transcription factors $2 / 3$ (SMADs2/3) at the Ser-Xxx-Ser motif at the carboxy-terminal tail ${ }^{16-18}$. Receptor-mediated phosphorylation of R-SMADs facilitates interaction with the coSMAD, SMAD4, followed by accumulation in the nucleus, where the SMAD complex co-operates with different transcriptional co-regulators to modulate the expression of hundreds of target genes in a cell-type- and context-dependent manner ${ }^{18-20}$.

Previously, we developed an endogenous transcriptional reporter cell line for the TGF $\beta$ pathway using CRISPR-Cas9 genome editing technology ${ }^{21}$ by inserting firefly (Photinus pyralis) luciferase and green fluorescent protein (GFP) at the native TGF $\beta$-responsive target gene plasminogen activator inhibitor 1 (PAI-1) locus (Fig. 1a). The transcription of $P A I-1$ is induced in response to TGF $\beta$ signals in different cell types in a SMAD-dependent manner ${ }^{22,23}$. Moreover, the promoter region of the endogenous PAI-1 gene has been frequently utilised in order to generate conventional luciferase-based overexpression reporter systems for the study of TGF $\beta$-mediated transcriptional regulation ${ }^{24}$. In order to identify novel regulatory components of the TGF $\beta$ pathway, we performed a pharmacological screen in this endogenous TGF $\beta$-responsive transcriptional reporter cell line using a panel of small molecules obtained from the MRC International Centre for Kinase Profiling at the University of Dundee. The panel consisted predominantly of selective and potent inhibitors of protein kinases, but also included a small number of compounds that target components of the ubiquitin-proteasome system (UPS). The screen identified salt-inducible kinases (SIKs), which are members of the AMP-activated protein kinase (AMPK)-related subfamily of serine-threonine specific kinases $^{25,26}$, as potential novel regulators of TGF $\beta$-mediated gene transcription. In this study, we have therefore investigated the role of SIKs in regulating the TGF $\beta$ signalling pathway.

\section{Results}

Identification of salt-inducible kinases as novel regulators of TGF $\beta$-mediated gene transcription

We tested the utility of the endogenous TGF $\beta$-responsive transcriptional reporter U2OS cell line (U2OS 2G) (Fig. 1a) for a pharmacological screen. Stimulation of wild-type (WT) U2OS and U2OS 2G cells with $\mathrm{TGF} \beta_{1}$ over $24 \mathrm{~h}$ resulted in time-dependent induction of PAI-1 and GFP expression, respectively (Fig. 1b), and comparable levels of SMAD3 $C$-terminal phosphorylation in both cell lines. TGF $\beta$ induced a significant increase in relative luciferase activity in U2OS $2 \mathrm{G}$ cells over unstimulated cells, which was blocked with SB505124, a selective inhibitor of the TGF $\beta$ type I receptor
(TGF $\beta R 1)$ kinases $^{27,28}$ (Fig. 1c). Similarly, TGF $\beta$-induced GFP expression in U2OS $2 \mathrm{G}$ cells is blocked with SB505124 (Fig. 1d). These data confirmed the suitability of U2OS $2 \mathrm{G}$ cells for pharmacological screens. A 96-well plate format pharmacological screen was performed to identify potential novel regulators of the TGF $\beta$ pathway (Fig. 1e). TGF $\beta$ R1 inhibitors SB-505124 (refs. ${ }^{27,28}$ ) and A 83-01 (ref. ${ }^{29}$ ) served as positive controls, while DMSO served as a negative control. All compounds were used at a final concentration of $1 \mu \mathrm{M}$. Both SB-505124 and A 8301 significantly inhibited TGF $\beta$-induced luciferase activity compared with DMSO controls (Fig. 1f, g). In addition, D4476 and LDN193189, also significantly inhibited TGF $\beta$-induced luciferase activity. D4476 was initially identified as an inhibitor of TGF $\beta$ R 1 (ref. ${ }^{30}$ ), although subsequent in vitro profiling revealed that it inhibited casein kinase 1 (CK1) with greater potency ${ }^{31}$. LDN193189 is an ATP-competitive inhibitor of the BMP type I receptor kinases ${ }^{32}$. However, at $1 \mu \mathrm{M}$ concentration it also inhibits the TGF $\beta R 1$ (ref. ${ }^{28}$ ). The majority of the compounds used in the screen did not significantly affect TGF $\beta$-induced luciferase reporter activity. Interestingly, however, we observed that HG-9-91-01, a potent ATPcompetitive inhibitor of salt-inducible kinase (SIK) isoforms ${ }^{33}$, significantly attenuated TGF $\beta$-induced luciferase activity (Fig. 1f, g), suggesting a possible role for SIKs in TGF $\beta$-induced transcription.

\section{Characterisation of SIK inhibitors in the context of TGF $\beta$ signalling}

To explore the role of SIKs in TGF $\beta$ signalling further, in addition to HG-9-91-01, we utilised MRT199665, a structurally distinct inhibitor of SIK isoforms ${ }^{33}$ (Fig. 2a). MRT199665 also suppressed TGF $\beta$-induced luciferase activity in U2OS 2 G cells, as potently as SB-505124 and HG9-91-01 (Fig. 2b). Both HG-9-91-01 and MRT199665 inhibited the phosphorylation of a known SIK substrate CRTC3 at S370 (refs. ${ }^{33-35}$ ) compared with DMSO control (Fig. 2c). Because kinase inhibitors often display off-target inhibition, we tested whether the attenuation of TGF $\beta$-induced luciferase activity by HG-9-91-01 and MRT199665 occurred as a result of the off-target inhibition of the TGFßR1 upstream of SMAD2/SMAD3 phosphorylation. HG-9-91-01 substantially inhibited TGF $\beta$-induced SMAD3 phosphorylation, to a similar extent as SB-505124, compared with DMSO controls, whereas MRT199665 did not (Fig. 2d), suggesting that HG-9-91-01 could inhibit either type I or type II TGF $\beta$ receptors. Indeed, at concentrations of $0.1,1$ and $10 \mu \mathrm{M}$ in vitro, HG-9-91-01 inhibited TGFßR1 (ALK5) kinase activity, whereas MRT199665 did not (Fig. 2e). Because of this off-target inhibition of TGF $\beta$ R 1 by HG-9-91-01, we decided to employ MRT199665 as the SIK inhibitor for subsequent experiments. 


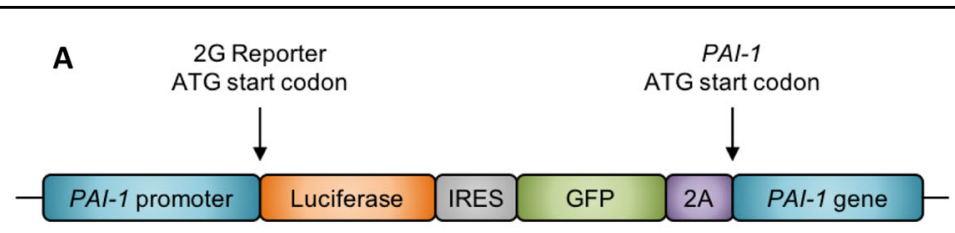

Integrated 2G TGF $\beta$ transcriptional reporter

B

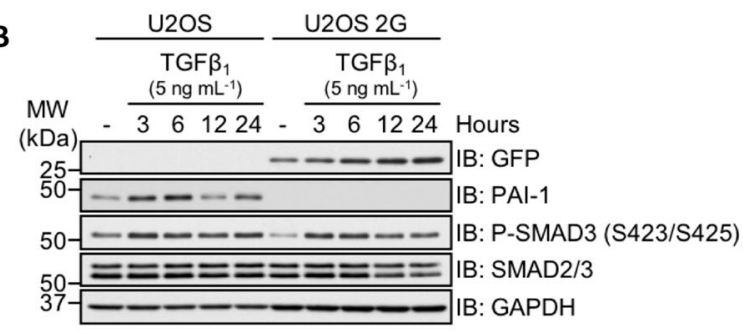

C

PAl1-luciferase

D
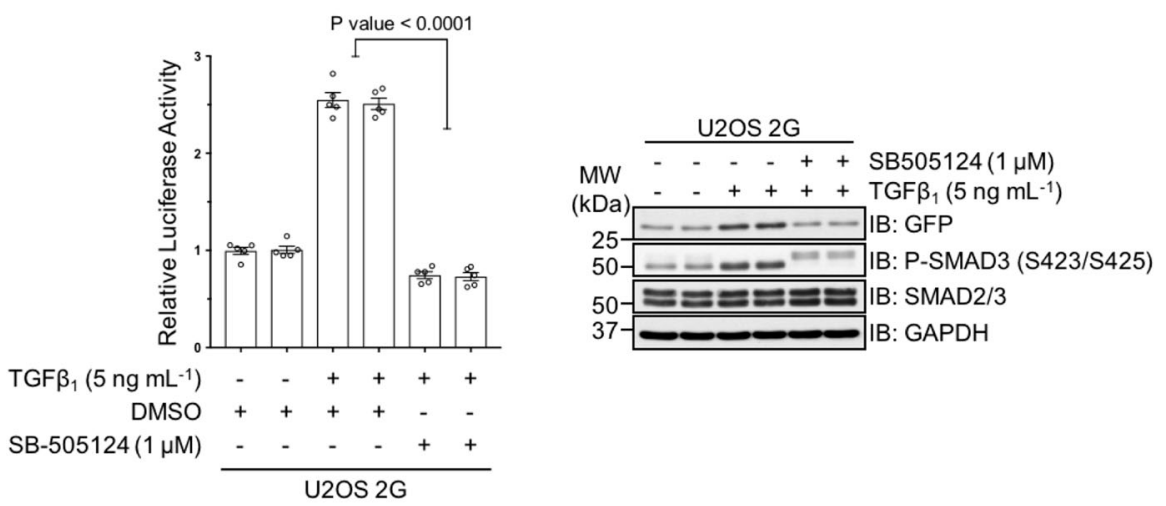

E Seed U2OS 2G
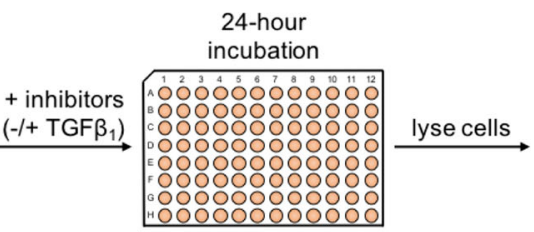

Luciferase

reporter cells

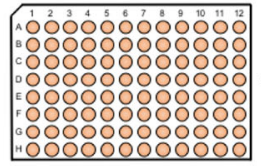

assay

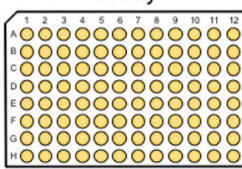

$\mathbf{F}$

G

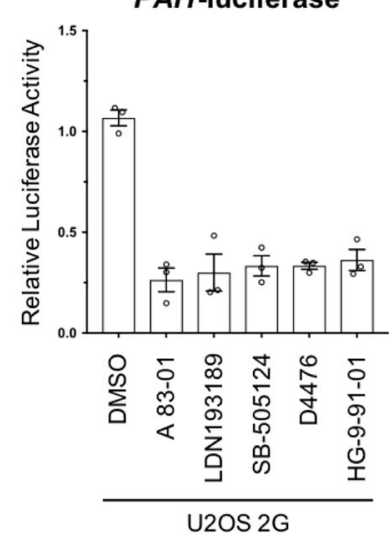

\begin{tabular}{|c|c|c|}
\hline $\begin{array}{c}\text { Mean Relative } \\
\text { Luciferase Activity } \\
( \pm \text { SEM) }\end{array}$ & Inhibitor & Target kinase \\
\hline $1.07 \pm 0.04$ & DMSO & Control \\
\hline $0.26 \pm 0.06$ & A 83-01 & TGF $\beta$ RI (ALK5) \\
\hline $0.30 \pm 0.09$ & LDN193189 & BMPRs (ALK2, ALK3) \\
\hline $0.33 \pm 0.05$ & SB-505124 & TGF $\beta R I$ (ALK4, ALK5, ALK7) \\
\hline $0.33 \pm 0.02$ & D4476 & CK1, TGF $\beta$ RI (ALK5) \\
\hline $0.36 \pm 0.05$ & HG-9-91-01 & SIKs \\
\hline
\end{tabular}

Fig. 1 (See legend on next page.) 
(see figure on previous page)

Fig. 1 Pharmacological screen in endogenous TGF $\beta$ transcriptional reporter cells. a Schematic representation of the dual-reporter cassette inserted in-frame with the ATG start codon of the endogenous PAI-1 gene in U2OS human osteosarcoma cells. b Immunoblot analysis of wild-type U2OS and U2OS $2 \mathrm{G}$ transcriptional reporter cell lines stimulated with TGF $\beta_{1}\left(5 \mathrm{ng} \mathrm{mL}^{-1}\right)$ for the indicated durations. Cell lysates were resolved via SDS-PAGE, and membranes were subjected to immunoblotting with the indicated antibodies. $\mathbf{c}$ Luciferase assay analysis of U2OS $2 \mathrm{G}$ transcriptional reporter cells incubated with either SB-505124 or DMSO control in the presence of TGF $\beta_{1}$ stimulation. $\mathbf{d}$ Immunoblot analysis of U2OS transcriptional reporter cells incubated with either SB-505124 or DMSO control in the presence of TGF $\beta_{1}$ stimulation. Cell lysates were resolved via SDS-PAGE, and membranes were subjected to immunoblotting with the indicated antibodies. e Schematic representation of the experimental workflow for the pharmacological screen in U2OS $2 \mathrm{G}$ transcriptional reporter cells. $\mathbf{f}, \mathbf{g}$ The top five hits obtained from three independent experiments that reduced TGF $\beta$-induced luciferase activity. Data indicate the mean luciferase activity values ( \pm SEM) relative to internal DMSO controls.

\section{MRT199665 attenuates the expression of endogenous TGF $\beta$ target genes}

Any compound that inhibits luciferase enzymatic activity could potentially yield a false-positive result in U2OS $2 \mathrm{G}$ cells. Therefore, to exclude this possibility for MRT199665, we tested whether the TGF $\beta$-induced GFP expression in U2OS 2G cells was affected by MRT199665. The TGF $\beta$-induced expression of GFP in U2OS $2 \mathrm{G}$ cells was inhibited with MRT199665, to the same extent as SB505124, compared with DMSO control (Fig. 3a), while the TGF $\beta$-induced SMAD2/SMAD3 $C$-terminal phosphorylation was unaffected by MRT199665 (Fig. 3a). Moreover, MRT199665 significantly attenuated TGF $\beta$-induced PAI-1 mRNA expression in WT U2OS cells (Fig. 3b). In WT A-172 human glioblastoma cells, MRT199665 also inhibited TGF $\beta$-induced expression of PAI-1 mRNA, as well as $S M A D 7$ and connective tissue growth factor (CTGF) mRNAs (Fig. 3c). These data demonstrate that MRT199665 inhibits TGF $\beta$-induced transcription of endogenous target genes in different cells without affecting SMAD2/SMAD3 phosphorylation.

\section{Genetic inactivation of SIK2/3 attenuates the TGF $\beta$-mediated induction of PAI-1 expression}

We employed genetic approaches to test the impact of SIK kinase activity on TGF $\beta$ signalling. SIKs are members of the AMP-activated protein kinase (AMPK)-related subfamily of serine-threonine protein kinases that require LKB1-mediated phosphorylation of a conserved threonine residue within the activation loop in order to become catalytically active $^{25,26}$ (Fig. 4a). In LKB1-deficient WT HeLa cells ${ }^{36-38}$, TGF $\beta_{1}$ induced a 1.5 -fold increase in PAI1 mRNA expression relative to unstimulated controls. However, stable overexpression of catalytically active LKB1 ( $\mathrm{LKB1}{ }^{\mathrm{WT}}$ ), but not the catalytically inactive mutant $\left(\mathrm{LKB} 1^{\mathrm{D} 194 \mathrm{~A}}\right)$, in WT HeLa cells, significantly enhanced the TGF $\beta$-induced transcription of PAI-1 mRNA (Fig. 4b), as well as PAI-1 protein levels (Fig. 4c), although the levels of $\mathrm{LKB} 1^{\mathrm{WT}}$ restored in HeLa cells were substantially higher than the LKB1 ${ }^{\mathrm{D} 194 \mathrm{~A}}$ mutant (Fig. 4c).

The catalytic activity of SIK isoforms can be ablated via mutation of the activation loop threonine to alanine ${ }^{39}$, which abolishes LKB1-mediated phosphorylation. Indeed, in mouse embryonic fibroblasts (MEFs) derived from embryos harbouring homozygous SIK2 $2^{\mathrm{T} 175 \mathrm{~A}}$ and SIK3 ${ }^{\text {T163A }}$ genotypes ${ }^{39}$, the phosphorylation of CRTC3 at S370 is substantially reduced compared with WT control MEFs (Fig. 4d). A time-course treatment of WT MEFs with TGF $\beta_{1}$ resulted in robust SMAD3 phosphorylation, and an increase in PAI-1 protein levels at $6 \mathrm{~h}$ (Fig. 4e). When homozygous SIK $2^{\mathrm{T} 175 \mathrm{~A}} / \mathrm{SIK} 3^{\mathrm{T} 163 \mathrm{~A}} \mathrm{MEFs}$ were subjected to TGF $\beta$ stimulation for $6 \mathrm{~h}$, the induction of PAI-1 protein expression was substantially attenuated, compared with WT MEFs, despite the observation of higher SMAD3 phosphorylation in the SIK2 $2^{\mathrm{T} 175 \mathrm{~A}}$ / SIK3 ${ }^{\text {T163A }}$ mutant MEFs (Fig. 4f). Consistent with this, the relative PAI-1 mRNA expression in response to TGF $\beta$ stimulation was significantly reduced in MEFs derived from two independent homozygous SIK2 $2^{\mathrm{T} 175 \mathrm{~A}} / \mathrm{SIK} 3^{\mathrm{T} 163 \mathrm{~A}}$ mice relative to WT MEFs (Fig. 4g).

\section{Impact of SIK isoforms on TGF $\beta$-dependent proliferative responses}

TGF $\beta$ inhibits epithelial cell proliferation, in part through transcriptional upregulation of cyclin-dependent kinase (CDK) inhibitors $\mathrm{p} 21^{\mathrm{CIP} 1}$ and $\mathrm{p} 27^{\mathrm{KIP} 1}$, and downregulation of the proto-oncogene $\mathrm{c}-\mathrm{Myc}^{1,4,7}$. In $\mathrm{HaCaT}$ cells, we observed an increase in endogenous p2 $7^{\mathrm{KIP} 1}$ and p21 ${ }^{\mathrm{CIP} 1}$ protein levels, and a decrease in c-Myc protein levels over a 24-h time course of TGF $\beta$ treatment (Fig. 5a). Rather surprisingly, treatment of $\mathrm{HaCaT}$ cells with MRT199665 resulted in increased expression of both p21 ${ }^{\mathrm{CIP} 1}$ and $\mathrm{p} 27^{\mathrm{KIP} 1}$, even in the absence of TGF $\beta$ treatment, and this increase was more pronounced after stimulation of cells with TGF $\beta$ compared with DMSO controls (Fig. 5b). This suggested that inhibition of SIKs alone may exert cytostatic effects. When we analysed the proliferation of $\mathrm{HaCaT}$ cells over a period of $170 \mathrm{~h}$, the control cells displayed a typical sigmoid growth curve, while TGF $\beta$ treatment caused a significant inhibition of proliferation after $100 \mathrm{~h}$ (Fig. 5c). Under these conditions, MRT199665 profoundly suppressed cell proliferation at all time points, regardless of TGF $\beta$ treatment (Fig. 5c). In line with this, when we analysed MEFs from Fig. 4f for $\mathrm{p} 27^{\mathrm{KIP} 1}$ levels, we also observed a substantial increase in $\mathrm{p} 27^{\mathrm{KIP} 1}$ levels in MEFs derived from homozygous SIK2 $2^{\mathrm{T} 175 \mathrm{~A}} / \mathrm{SIK} 3^{\mathrm{T} 163 \mathrm{~A}} \mathrm{KI}$ mice relative to 
A<smiles>COc1ccc(N(C(=O)Nc2c(C)cccc2C)c2cc(Nc3ccc(N4CCN(C)CC4)cc3)ncn2)c(OC)c1</smiles>

HG-9-91-01

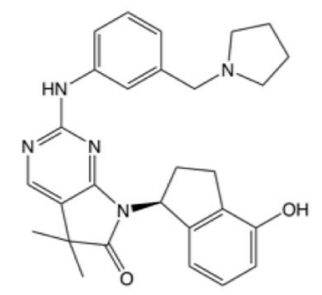

MRT199665
B

PAl1-luciferase

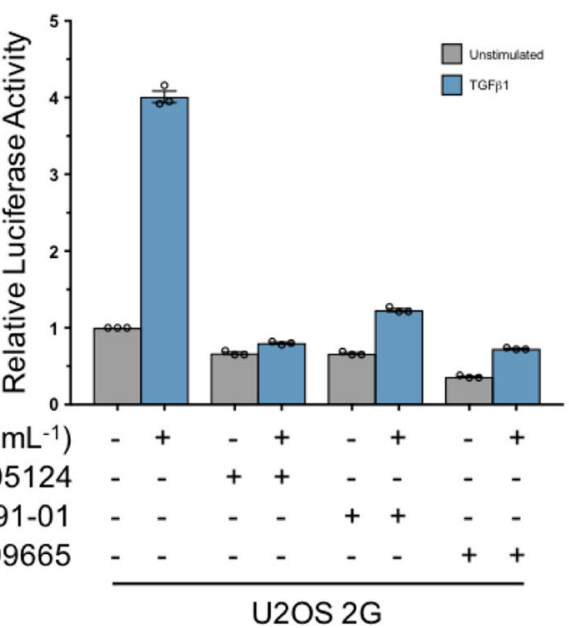

C

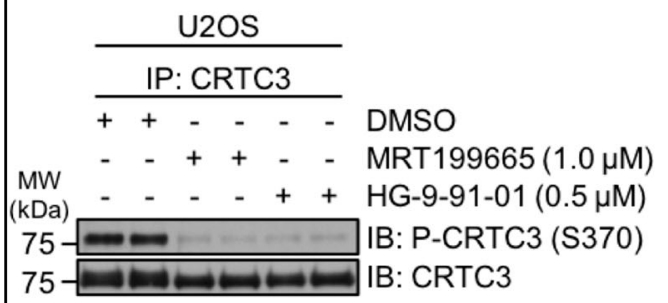

D

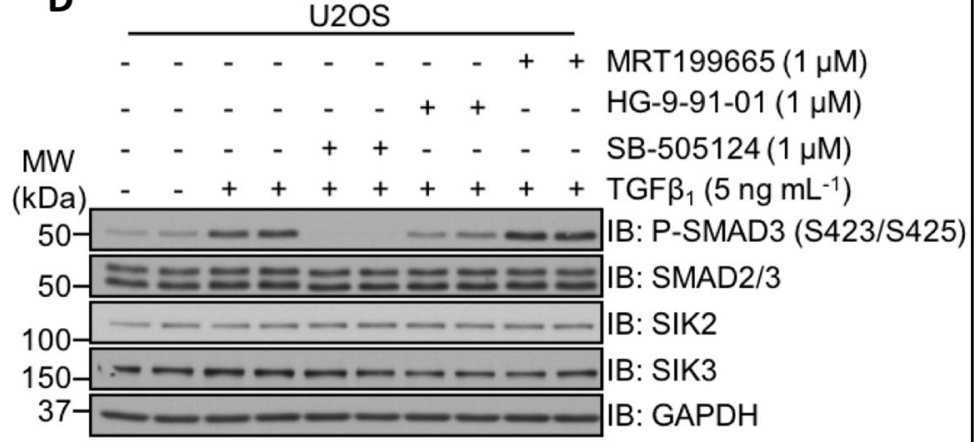

E

Inhibitor conc. $(\mu \mathrm{M})$

1.0

10.0

0.1

$\%$ Activity ( \pm SD)

$4.8 \pm 0.82$

$102.2 \pm 4.57$
\% Activity ( \pm SD)

$3.3 \pm 0.13$

$94.3 \pm 0.29$
$\%$ Activity ( \pm SD)

$3.0 \pm 0.02$

$97.7 \pm 1.22$

Fig. 2 Characterisation of pharmacological SIK inhibitors in the context of TGF $\beta$ signaling. a The chemical structures of HG-9-91-01 and MRT199665, ATP-competitive small-molecule inhibitors of SIK isoforms. b Luciferase assay analysis of U2OS 2G transcriptional reporter cells incubated with DMSO, SB-505124, HG-9-91-01 or MRT199665, in the presence or absence of TGF $\beta_{1}$ stimulation. c Immunoblot analysis of endogenous CRTC3 phosphorylation in wild-type U2OS cells following incubation with DMSO, MRT199665 or HG-9-91-01. Cell lysates were subjected to endogenous CRTC3 immunoprecipitation (IP) and subsequently resolved via SDS-PAGE. Membranes were subjected to immunoblotting with the indicated antibodies. $\mathbf{d}$ Immunoblot analysis of wild-type U2OS cells incubated with SB-505124, HG-9-91-01 or MRT199665 in the presence of TGF $\beta_{1}$ stimulation. Cell lysates were resolved via SDS-PAGE, and membranes were subjected to immunoblotting with the indicated antibodies. e In vitro kinase assay analysis of recombinant constitutively active TGFBR1 (ALK5) in the presence of HG-9-91-01 or MRT199665 at the three indicated concentrations. Values denote the mean percentage activity remaining $( \pm \mathrm{SD})$.

WT mice, irrespective of TGF $\beta$ stimulation (Fig. $5 \mathrm{~d}$ ), suggesting that SIK kinase activity plays a fundamental role in suppressing $\mathrm{p} 27^{\mathrm{KIP} 1}$ protein levels. To further confirm that SIK inhibition promotes cytostasis independent of TGF $\beta$ stimulation, we exploited SMAD3 ${ }^{-/-} \mathrm{HaCaT}$ cells, and showed that treatment of both WT and $\mathrm{SMAD3}^{-1-}$ $\mathrm{HaCaT}$ cells with MRT199665 resulted in an increase in p21 ${ }^{\mathrm{CIP} 1}$ and $\mathrm{p} 27^{\mathrm{KIP} 1}$ levels compared with untreated control cells (Fig. 5e).

In many epithelial cells, TGF $\beta$-induced cytostasis, through the induction of $\mathrm{p} 21^{\mathrm{CIP} 1}$ and $\mathrm{p} 27^{\mathrm{KIP} 1}$, and suppression of c-Myc, is often necessary for subsequent TGF $\beta$-dependent cell fates, such as differentiation, EMT and apoptosis. Our unexpected findings that inhibition of 


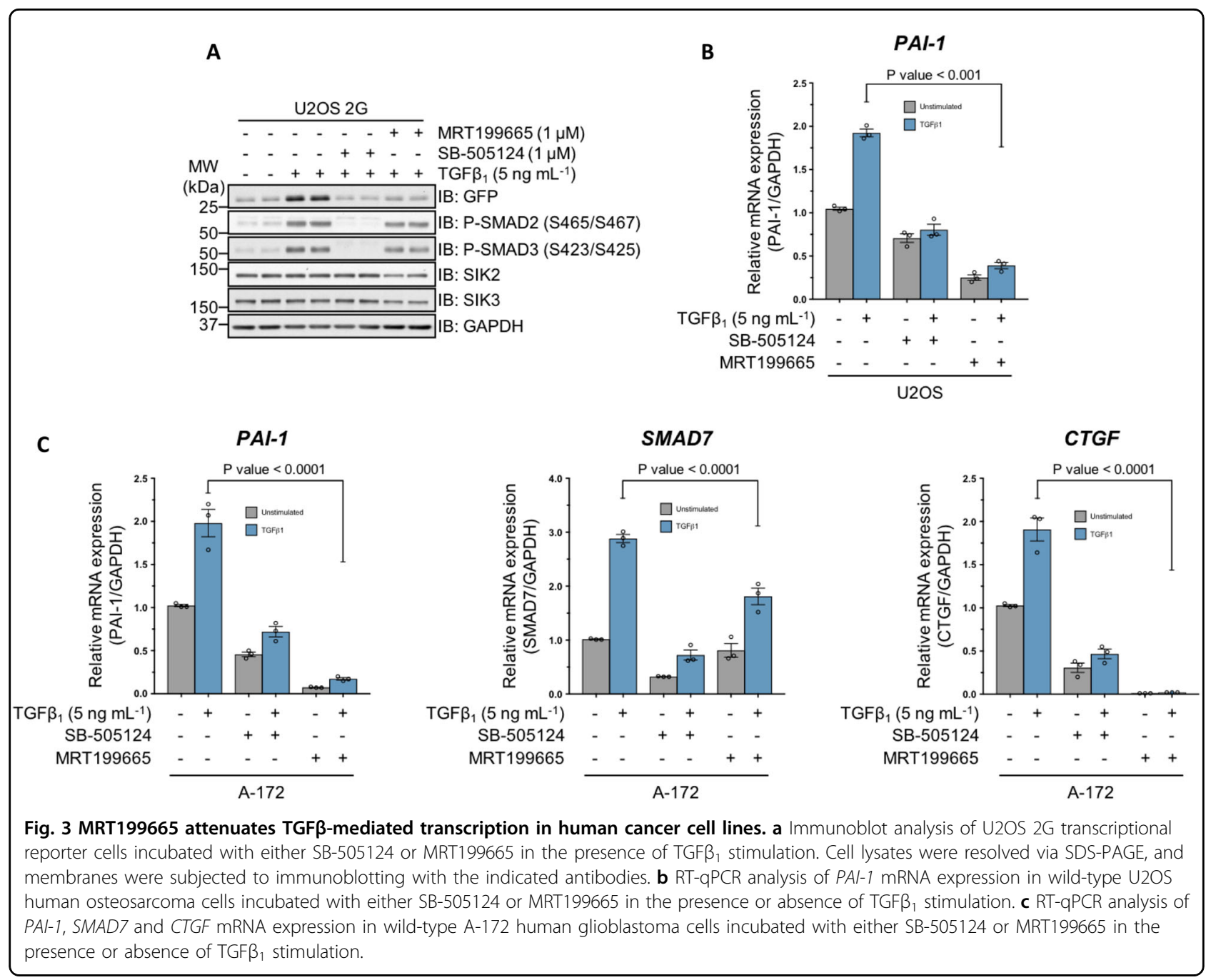

SIK isoforms induces the expression of $\mathrm{p} 21^{\mathrm{CIP} 1}$ and $\mathrm{p} 27^{\mathrm{KIP} 1}$ levels, independent of TGF $\beta$, prompted us to explore whether TGF $\beta$-induced epithelial cell fates are sensitised by SIK inhibitors. We therefore sought to investigate whether inhibition of SIK isoforms sensitises cells to TGF $\beta$-induced EMT and apoptosis.

\section{Pharmacological inhibition of SIKs potentiates TGF $\beta$-mediated apoptosis}

NMuMG murine mammary epithelial cells undergo both EMT and apoptosis upon TGF $\beta$ stimulation ${ }^{40-44}$. When we tested the effect of MRT199665 on TGF $\beta$-induced EMT in NMuMG cells, which usually takes around $24-48 \mathrm{~h}$, it became apparent that there was profound cell death within $12-24 \mathrm{~h}$, prompting us to investigate apoptosis. The apoptotic response to TGF $\beta$ is mediated in part by the executioner cysteine-aspartic acid protease, caspase-3. Caspase- 3 is synthesised as an inactive proenzyme, and requires proteolytic cleavage in order to become catalytically active. Apoptosis can thus be monitored via the detection of the cleaved, and hence activated, form of caspase-3. Furthermore, activated caspase-3 mediates the proteolytic cleavage of poly(ADP-ribose) polymerase (PARP), which can also be used to monitor apoptosis. Stimulation of NMuMG cells with TGF $\beta_{1}$ over a period of $72 \mathrm{~h}$ induced the activation of caspase- 3 and subsequent cleavage of PARP, with maximal cleavage observed at $24 \mathrm{~h}$ (Fig. 6a). The expression of the pro-apoptotic factor Bim was observed at $48-72 \mathrm{~h}$ (Fig. 6a). In these cells, SIK inhibitors HG-9-91-01 and MRT199665 resulted in reduction of phospho-CRTC3S370 (Fig. 6b). The TGF 3 -induced cleavage of caspase-3 and PARP at $24 \mathrm{~h}$ was blocked by SB-505124 (Fig. 6c). Interestingly, in cells incubated with MRT199665 and TGF $\beta_{1}$, the appearance of cleaved caspase-3 and PARP was substantially enhanced, compared with TGF $\beta$-treated DMSO controls (Fig. 6c). Under these conditions, the expression of pro-apoptotic factors BIM, BAD, BAK and BIK did not increase when cells were treated with MRT199665 and TGF $\beta_{1}$ compared with TGF $\beta$-treated 


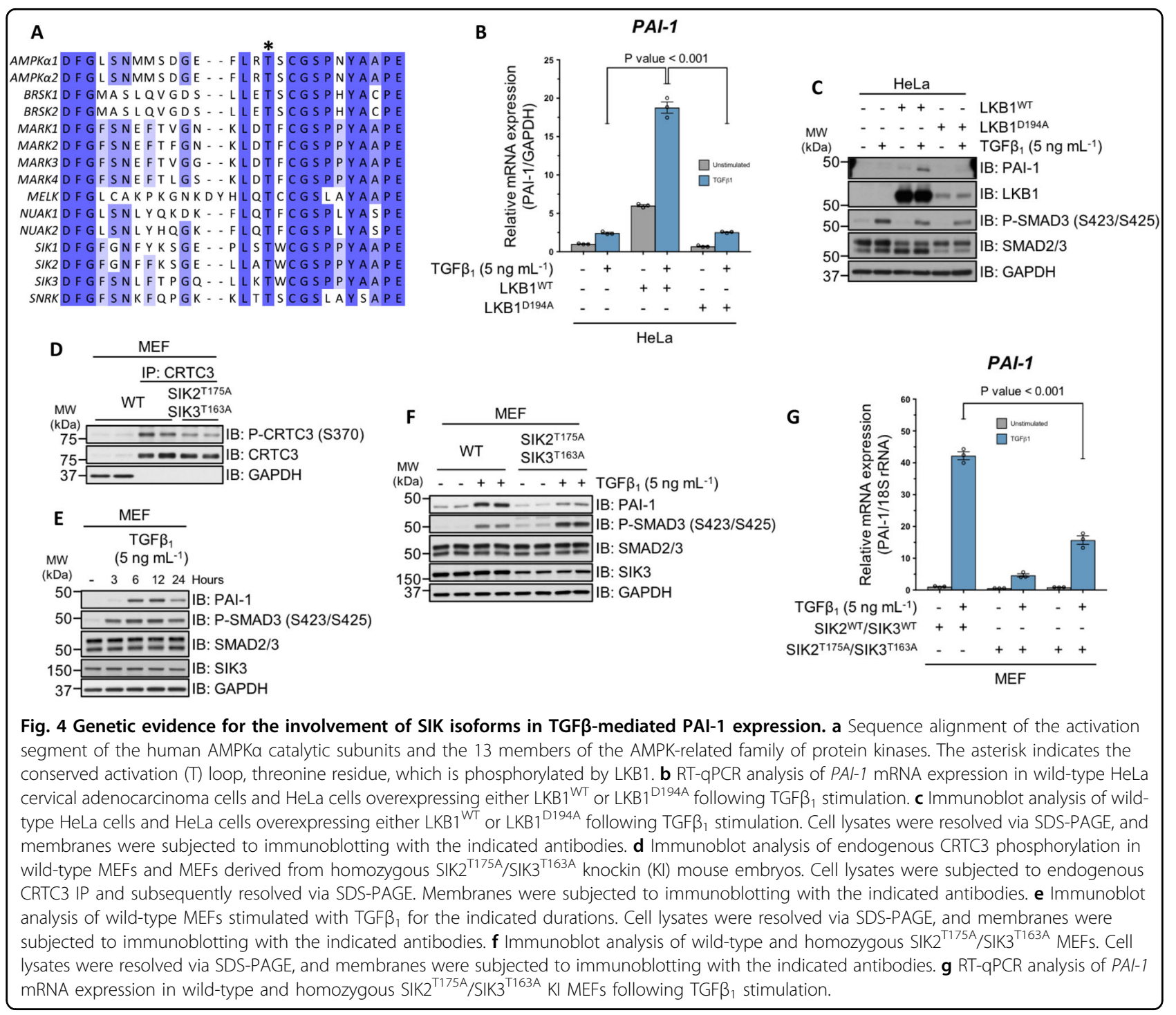

DMSO controls (Fig. 6c). However, in cells treated with MRT199665 and TGF $\beta_{1}$, the levels of apoptosis suppressor protein MCL-1 were substantially attenuated, compared with TGF $\beta$-treated DMSO controls (Fig. 6c). In the absence of TGF $\beta_{1}$, MRT199665 alone did not induce the cleavage of caspase- 3 and PARP (Fig. 6d). Furthermore, MRT199665 + TGF $\beta_{1}$ treatment resulted in the maximal and more pronounced appearance of cleaved caspase- 3 and PARP much earlier $(12 \mathrm{~h})$ than TGF $\beta_{1}$ alone treatment (Fig. 6d). When we monitored apoptosis using Annexin $\mathrm{V}$ and DAPI staining, treatment of NMuMG cells with TGF $\beta$ for $24 \mathrm{~h}$ resulted in a substantial increase in Annexin V-positive apoptotic cells over controls, while this was reversed by SB-505124. Treatment of cells with MRT199665 significantly enhanced TGF $\beta$-induced apoptosis (Fig. 6e). Similarly, when we analysed cell viability, TGF $\beta_{1}$ treatment resulted in a decrease in the number of viable cells compared with
DMSO controls, while this was reversed by SB-505124 (Fig. 6f). In contrast, treatment of cells with MRT199665 resulted in almost complete loss of viable cells (Fig. 6f). Collectively, these results indicate that inhibition of SIK isoforms by MRT199665 can potentiate TGF $\beta$-mediated apoptotic cell death in NMuMG cells.

Previous reports have revealed that the clinically approved tyrosine kinase inhibitors (TKIs) bosutinib and dasatinib are also capable of inhibiting SIK isoforms, with in vitro $\mathrm{IC}_{50}$ values in the low nanomolar range $e^{45,46}$ (Fig. 7a). Both bosutinib and dasatinib inhibit the kinase activity of the BCR-Abl fusion, as well as Src and BTK (Fig. 7b), and are used to treat Philadelphia chromosomepositive $(\mathrm{Ph}+)$ chronic myelogenous leukaemia (CML) and acute lymphoblastic leukaemia (ALL) ${ }^{47,48}$. In WT U2OS cells, both compounds reduced the phosphoCRTC3 (S370) levels compared with DMSO controls, suggesting effective SIK inhibition (Fig. 7c). Like 


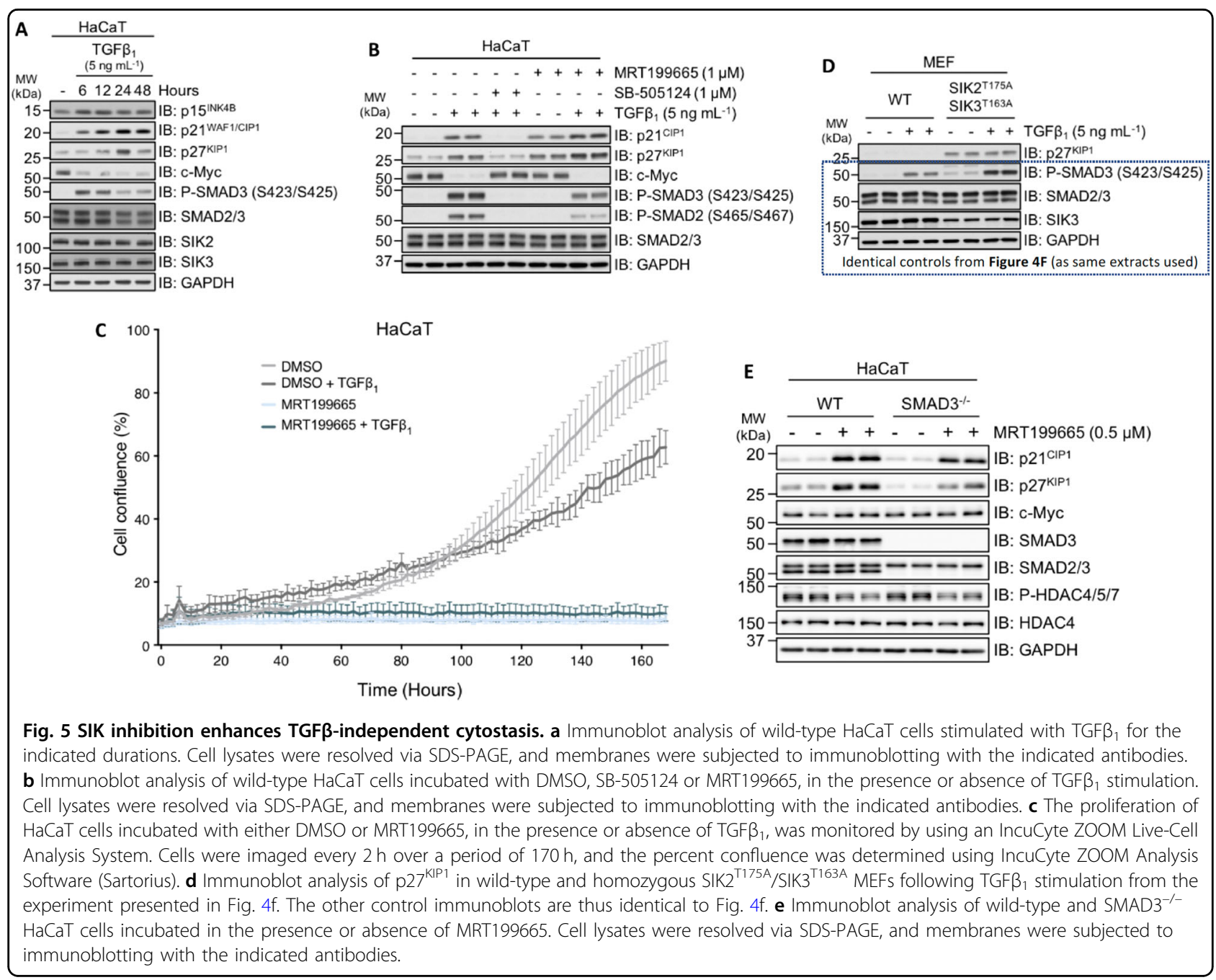

MRT199665, neither bosutinib nor dasatinib inhibited the TGF $\beta$-induced phosphorylation of SMAD2/SMAD3, but both inhibited the TGF $\beta$-induced expression of GFP in U2OS $2 \mathrm{G}$ cells (Fig. 7d), and endogenous PAI-1 in WT U2OS cells (Fig. 7e). As in U2OS cells, in NMuMG cells, neither compound affected the TGF $\beta$-induced phosphorylation of SMAD2/3 relative to controls (Fig. 7f). Excitingly, treatment of NMuMG cells with bosutinib for $24 \mathrm{~h}$ substantially enhanced the TGF $\beta$-induced levels of cleaved caspase- 3 and PARP to a similar extent as MRT199665 (Fig. 7g), suggesting that the increased TGF $\beta$-induced apoptosis caused by bosutinib is likely due to its ability to inhibit SIK isoforms.

\section{SIKs do not appear to affect SMAD2/3 phosphorylation and their nuclear translocation directly}

We sought to investigate the molecular mechanisms by which SIK2/SIK3 might regulate TGF $\beta$ signalling. To explore whether SIKs exert effects on TGF $\beta$ signalling through direct phosphorylation of SMAD proteins, in vitro kinase assays were performed. GST-SIK2 and GST-SIK3, but not MBP-SIK1, phosphorylated SMAD2, SMAD3 and SMAD4 in vitro (Fig. S1), while SIK inhibitor HG-9-91-01 blocked SMAD3 phosphorylation (Fig. S2A). Mass spectrometry identified Thr247 as the predominant SIK $2 / 3$ phosphorylated residue on SMAD3. This residue is conserved in SMAD2, SMAD3, SMAD4 and SMAD9 proteins (Fig. 8a). The TGF $\beta$-induced transcription of PAI-1 has been previously reported to be specific to SMAD3 $\left(\right.$ refs. $\left.{ }^{23,49}\right)$. Consistent with this, treatment of wild-type and $\mathrm{SMAD}^{-/-} \mathrm{HaCaT}$ cells with human $\mathrm{TGF}_{1}$ resulted in Cterminal phosphorylation of SMAD2; however, PAI-1 expression was completely abrogated in $\mathrm{SMAD}^{-/-}$cells but not in WT cells (Figs. 8b and S2B). Transient restoration of SMAD3 expression with FLAG-SMAD3 ${ }^{\mathrm{WT}}$ was sufficient to partially restore TGF $\beta$-induced PAI-1 expression (Fig. 8b). However, restoration of the SIK-phosphodeficient mutant FLAG-SMAD3 ${ }^{\mathrm{T} 247 \mathrm{~A}}$ in $\mathrm{SMAD3}^{-/-}$cells also restored TGF $\beta$-induced PAI-1 expression, to similar levels observed with SMAD3 ${ }^{\mathrm{WT}}$ (Fig. $8 \mathrm{~b}$ ), suggesting that 


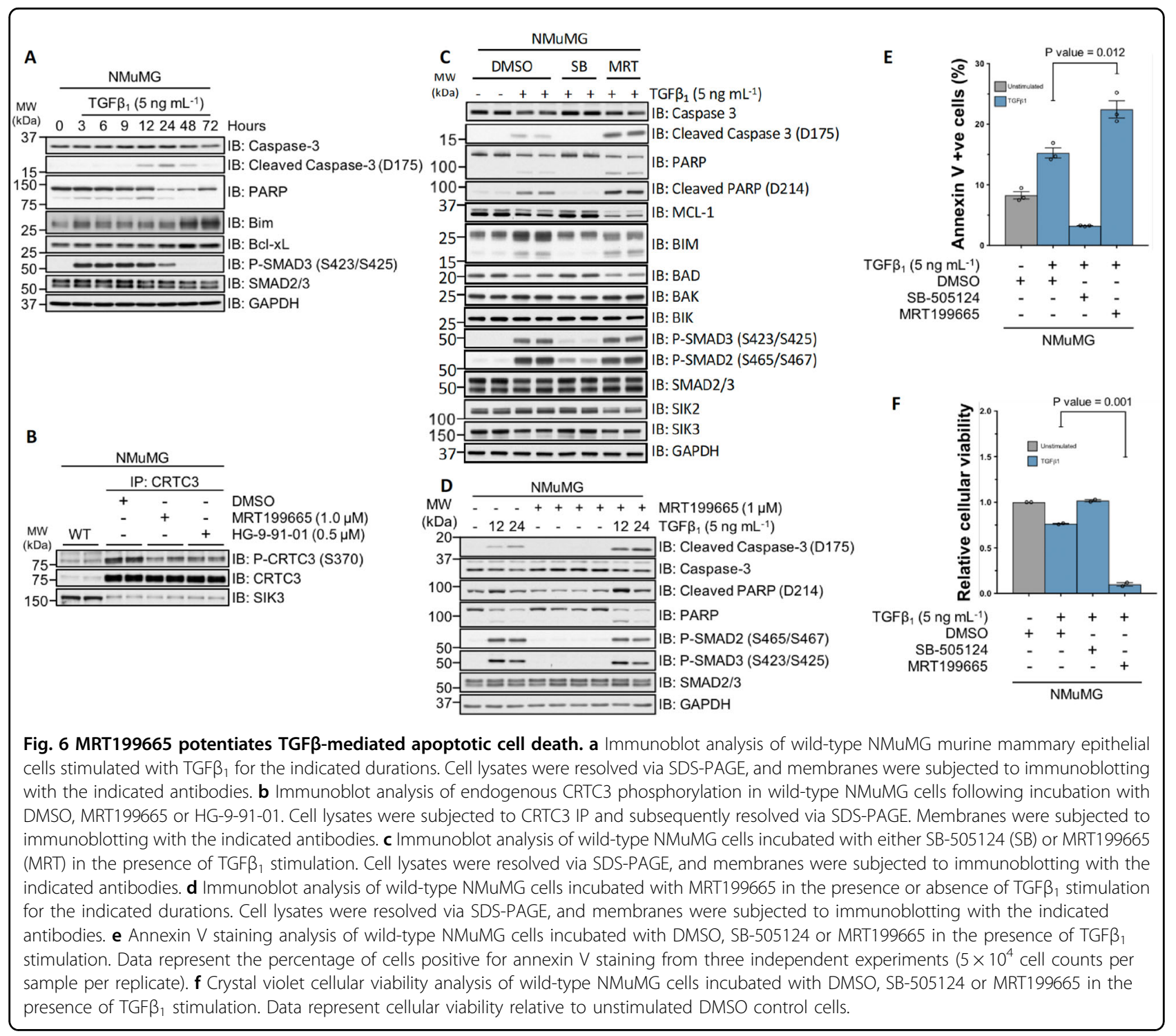

phosphorylation of SMAD3 at Thr247 by SIKs is unlikely to explain the effects of SIKs in TGF $\beta$ signalling.

Next, we tested whether SIK2/SIK3 inhibition disrupts the formation of SMAD2/SMAD3-SMAD4 complexes, or nuclear accumulation of SMADs. In U2OS cells stably overexpressing GFP-SMAD4, neither the basal nor TGF $\beta$-induced increase in co-precipitation of SMAD2/3 in GFP-SMAD4 IPs was affected by treatment of cells with MRT199665 (Fig. 8c). TGF $\beta$ induced a robust nuclear accumulation of phosphorylated SMAD2 and SMAD3 levels in nuclear fractions over unstimulated conditions, or when cells were treated with SB-505124 (Fig. 8d). MRT199665 treatment did not affect the cytoplasmic/nuclear distribution of phosphorylated SMAD2/SMAD3 relative to controls in both unstimulated and TGF $\beta_{1}$-stimulated conditions (Fig. 8d).
Consistent with this, in cells stably overexpressing GFPSMAD2, MRT199665 did not prevent the nuclear translocation of GFP-SMAD2 following TGF $\beta_{1}$ stimulation when analysed via immunofluorescence (IF) (Fig. 8e). As inhibition of SIK isoforms with MRT199665 does not appear to impact the formation of the SMAD2/ 3-SMAD4 complex or the nuclear accumulation of phosphorylated SMAD2/3, the effect of MRT199665 is likely to occur further downstream.

\section{Discussion}

In this study, we identified inhibitors of SIK isoforms as novel candidates for the inhibition of TGF $\beta$-induced transcription. We established that inhibiting SIK protein kinase activity, both pharmacologically and genetically, attenuates the TGF $\beta$-induced expression of endogenous 


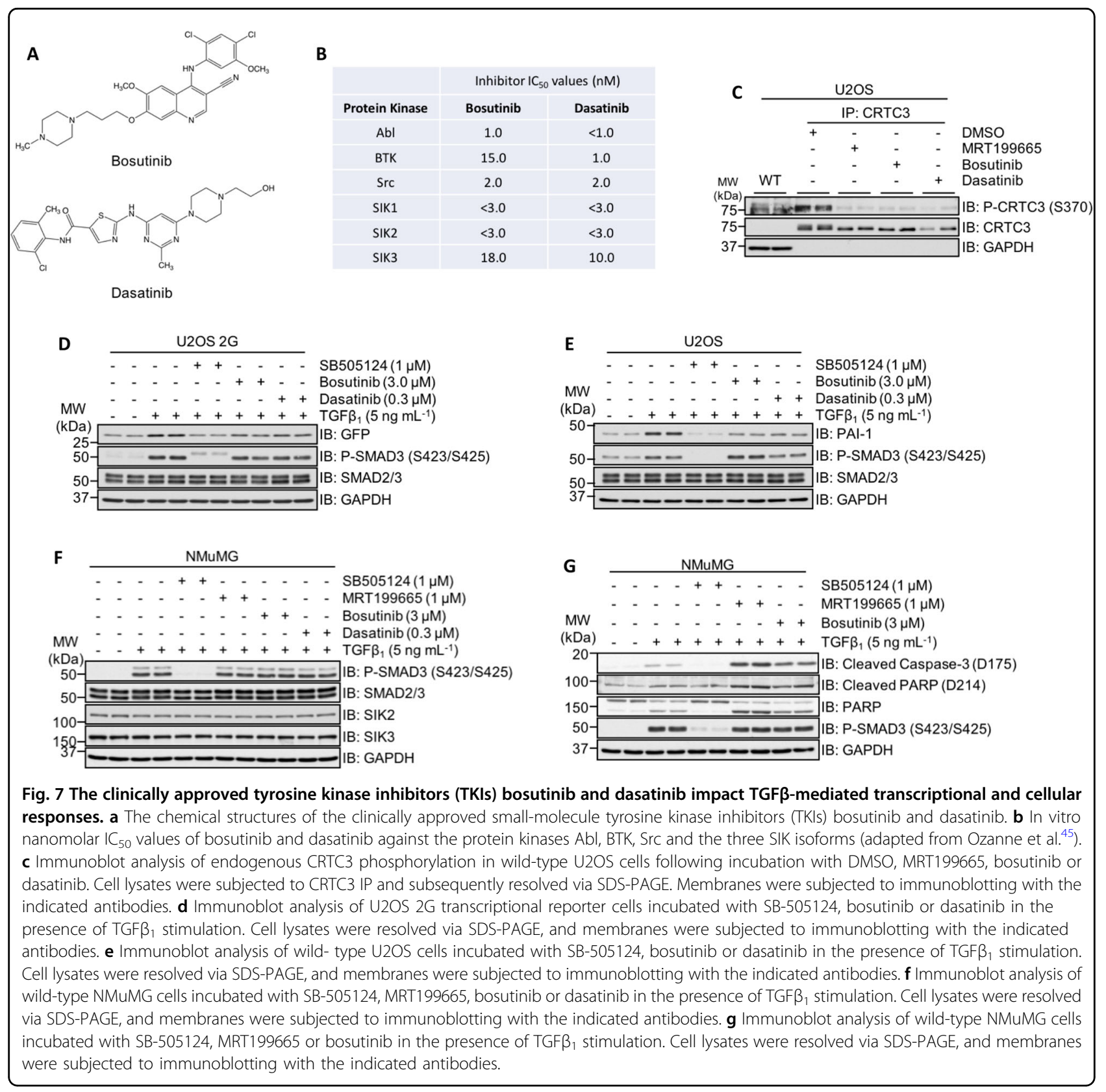

PAI-1 transcript and protein in different cells. Moreover, the attenuation of TGF $\beta$-induced PAI- 1 by MRT199665 occurred without affecting phosphorylation of SMAD proteins, the SMAD2/SMAD3-SMAD4 interaction or the nuclear accumulation of activated SMADs. We propose that SIK isoforms function at the level of transcriptional regulation in the context of TGF $\beta$ signalling.

In every cell line we tested, TGF $\beta$-induced endogenous PAI-1 transcript and protein levels were reduced by both pharmacological and genetic ablation of SIK kinase activity. PAI-1 is a serine protease inhibitor (Serpin) that functions as the physiological inhibitor of the serine proteases tissuetype plasminogen activator ( $\mathrm{t}-\mathrm{PA}$ ) and urokinase-type plasminogen activator ( $\mathrm{u}-\mathrm{PA})$, and controls fibrinolysis. Increased plasma levels of PAI-1 have been associated with a number of diseases, including thrombotic vascular disorders $^{50}$. As inhibition of SIK isoforms attenuates TGF $\beta$-induced expression of PAI-1, pharmacological SIK inhibitors may have novel therapeutic potential if they demonstrably suppress excessive PAI-1 levels in vivo.

SIK1 was previously linked to the regulation of TGF $\beta$ signalling $^{51,52}$, in which it was shown that SIK1 was a direct transcriptional target of TGF $\beta$ signalling, and played a role in the degradation of ALK5 through SIK1/ SMAD7/SMURF2 complex. During the course of our experiments, we did not observe any change in protein 


\section{A}
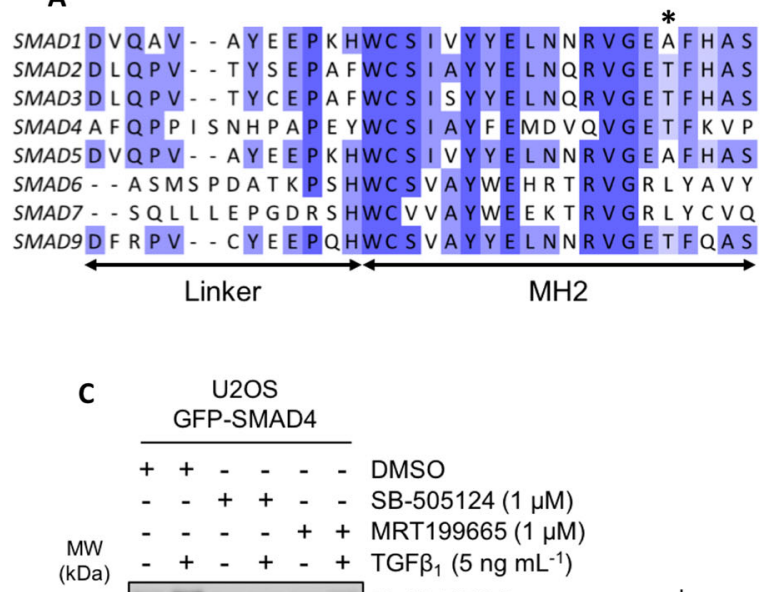

$(\mathrm{kDa})-+-+-+\mathrm{TGF}_{1}(5 \mathrm{ng}$
$50-\cdots$

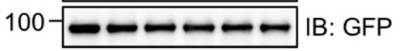

$100-\ldots--\ldots$ IB: SMAD4

$50-$ - - IB: P-SMAD3 (S423/S425)

$50=$ \#=ニ IB: SMAD2/3

$100-\longrightarrow-\ldots$ IB: SMAD4

$100--\longrightarrow-\longrightarrow$ IB: GFP

37

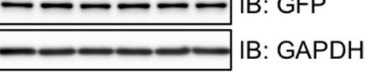

\section{D}

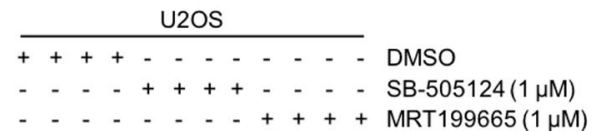

- - - - - - + + + + MRT199665 (1 $\mu \mathrm{M})$

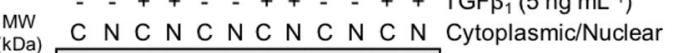

\begin{tabular}{l} 
(kDa) C N C N C N C N C N C N Cytoplasmic/Nuclear \\
$50-1-\infty-\infty$ \\
\hline
\end{tabular}

50- - - - - IB: P-SMAD3 (S423/S425)

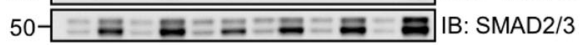

$75-\equiv \equiv \equiv \equiv \equiv \mathrm{IB}: \operatorname{Lamin} \mathrm{A} / \mathrm{C}$

$50-\overline{-}-\quad-\quad-\quad-\quad$ IB: Alpha Tubulin
B

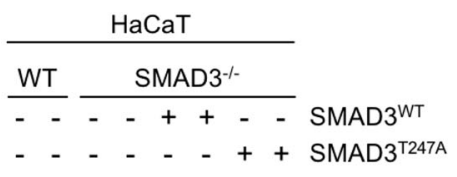

$\underset{\mathrm{MWa}}{\mathrm{kDa}}+++-+++\mathrm{TGF}_{1}\left(5 \mathrm{ng} \mathrm{mL}^{-1}\right)$

$50-= \pm--m=-m$ IB: SMAD2/3

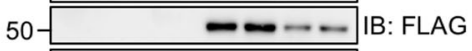

- -20 IB: P-SMAD2 (S465/S467)

$37 \begin{array}{ll}-\infty-\ldots-\ldots-\infty & \text { IB: PAI-1 } \\ -\infty-\ldots \text { IB: GAPDH }\end{array}$

E

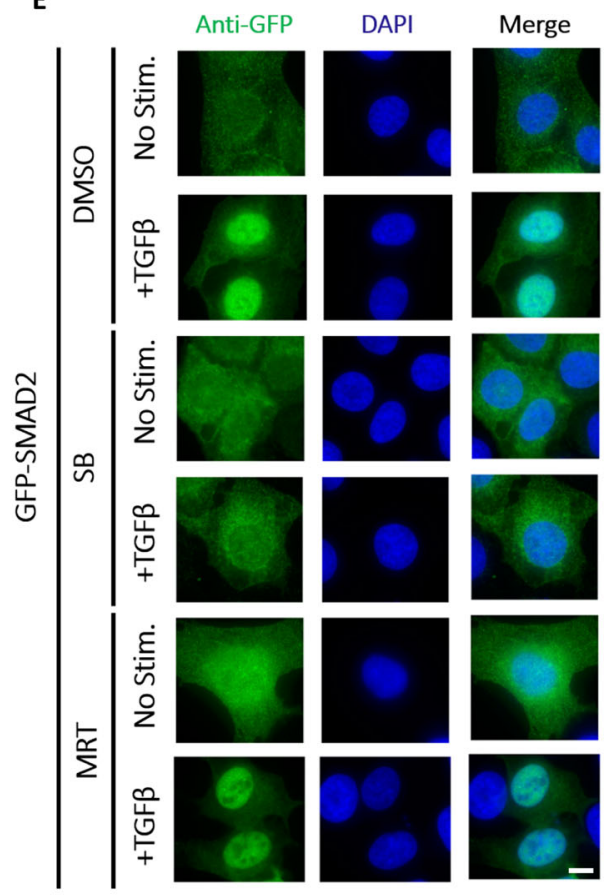

Fig. 8 SIK2 and SIK3 isoforms phosphorylate SMAD3 in vitro; however, MRT199665 does not affect SMAD interaction or nuclear translocation. a Sequence alignment of the eight human SMAD proteins. The asterisk indicates the amino acid residue in recombinant SMAD3 (Thr247) that was identified via phosphorylation-site mapping analysis. b Immunoblot analysis of wild-type HaCaT cells and SMAD3 ${ }^{-/-}$cells following transient overexpression of either FLAG-SMAD3 ${ }^{\mathrm{WT}}$ or FLAG-SMAD3 ${ }^{\mathrm{T} 247 \mathrm{~A}}$ mutant, in the presence or absence of TGF $\beta_{1}$ stimulation. Cell lysates were resolved via SDS-PAGE, and membranes were subjected to immunoblotting with the indicated antibodies. c U2OS cells stably expressing GFP-SMAD4 were incubated with DMSO, SB-505124 or MRT199665 in the presence or absence of TGF $\beta_{1}$ stimulation. Cell lysates were subjected to GFP immunoprecipitation and resolved via SDS-PAGE. Membranes were subjected to immunoblotting with the indicated antibodies. d Immunoblot analysis of SMAD2 and SMAD3 localisation in wild-type U2OS cells following incubation with DMSO, SB-505124 or MRT199665, in the presence or absence of TGF $\beta_{1}$ stimulation. Cell lysates were separated into cytoplasmic (C) and nuclear (N) fractions, resolved via SDS-PAGE and membranes were subjected to immunoblotting with the indicated antibodies. e Immunofluorescence analysis of U2OS cells stably expressing GFP-SMAD2 following incubation with DMSO, SB-505124 (SB) or MRT199665 (MRT) in the presence or absence of TGF $\beta_{1}$ stimulation (images are representative). Scale bar indicates $10 \mu \mathrm{m}$.

expression of either SIK2 or SIK3 upon TGF $\beta$ signalling, suggesting that unlike SIK1, these two isoforms are not transcriptional targets of TGF $\beta$ signalling. Our data indicate that the inhibition of the kinase activity of SIK2 and SIK3 is sufficient to suppress the TGF $\beta$-induced upregulation of PAI-1, whereas RNAi- mediated depletion of SIK1 has been reported to enhance PAI-1 mRNA expression in response to TGF $\beta$ stimulation $^{51}$. It is therefore apparent that the exact roles of the different SIK isoforms in regulating TGF $\beta$ signalling remain to be elucidated and are most likely context dependent. 
The precise mechanisms by which SIK isoforms regulate the TGF $\beta$-induced expression of PAI-1 or other genes remain to be resolved. As serine-threonine protein kinases, SIK isoforms act by phosphorylating protein substrates. In the case of TGF $\beta$ signalling, these could be components of the SMAD-transcriptional complexes or key transcriptional modulators, enhancers, suppressors and/or adaptors that modulate the function of these transcriptional cofactors in order to control the transcriptional activity of SMAD2/SMAD3. Unless the core SMAD2/3 transcriptional complexes are found to be substrates of SIKs, the impact of SIKs in TGF $\beta$ target gene transcription is likely to be determined by whether the individual target gene promoters recruit specific SIK substrates. It is known that SMAD2/SMAD3 do not directly regulate target gene transcription, but instead facilitate the recruitment of various transcriptional coactivators/co-repressors or histone-modifying enzymes ${ }^{20}$. SIKs have been reported to regulate the Toll-like receptor (TLR) signalling through their ability to phosphorylate the transcriptional coactivator CRTC3 and so reduce CREBdependent transcription of the $I L 10$ gene $^{33}$. It is therefore conceivable that SIKs may employ similar mechanisms to regulate SMAD-associated transcriptional cofactors to modulate the transcription of specific subsets of TGF $\beta$-target genes. A phospho-proteomic approach using both SIK inhibitors and SIK2 ${ }^{\mathrm{T} 175 \mathrm{~A}} / \mathrm{SIK}^{\mathrm{T} 163 \mathrm{~A}}$ MEFs might uncover potential SIK substrates that underpin the regulation of TGF $\beta$-induced transcription of distinct genes.

In many epithelial cell types, TGF $\beta$-induced cytostasis, through $\mathrm{p} 15^{\mathrm{INK} 4 \mathrm{~B}}, \mathrm{p} 21^{\mathrm{CIP} 1}$ and $\mathrm{p} 27^{\mathrm{KIP} 1}$ (refs. ${ }^{1,4}$ ), is often followed by context-dependent cell fates, such as differentiation, EMT or apoptosis ${ }^{53,54}$. Interestingly, inhibition of SIKs induced $\mathrm{p} 21^{\mathrm{CIP} 1}$ and $\mathrm{p} 27^{\mathrm{KIP} 1}$ expression independently of TGF $\beta$ stimulation. Perhaps due in part to this, SIK inhibitors sensitise NMuMG cells for TGF $\beta$-induced apoptosis. These observations imply that SIK inhibitors could be employed to sensitise cancer cells for apoptosis in those cells that TGF $\beta$ induces apoptosis. This could be easily tested by using clinically approved anticancer drugs dasatinib and bosutinib that inhibit SIK isoforms in addition to their intended targets in a number of cancer cell types, including multiple Burkitt's lymphoma (BL) cell lines ${ }^{42,55-57}$, hepatocellular carcinoma ${ }^{58}$ and prostate carcinoma cells $\mathrm{s}^{59-61}$ that have been reported to undergo apoptosis in response to TGF $\beta$.

Our findings place SIK isoforms as modulators of a subset of TGF $\beta$-induced transcriptional and physiological responses. Understanding these in detail will allow targeting of selective TGF $\beta$ responses, thereby limiting potential consequences of inhibiting the TGF $\beta$ pathway in its entirety. Of course, as discussed above, SIKs themselves are known to control other pathways, including immune signalling, and these need to be considered carefully. Taking into consideration that the clinically approved TKIs dasatinib and bosutinib, which also potently inhibit SIK isoforms ${ }^{45,46}$, are administered to patients safely, it is conceivable that more specific SIK inhibitors could be applied to target certain TGF $\beta$-associated pathologies.

\section{Materials and methods \\ Antibodies}

For Western immunoblotting analysis, all primary IgG antibodies were used at 1:1000 dilution unless otherwise stated. Anti-Phospho-SMAD3 (S423/S425) Rabbit polyclonal IgG (600-401-919) was purchased from Rockland Inc. Anti-GFP Mouse monoclonal IgG (11814460001) was purchased from Roche. Anti-Phospho-SMAD2 (S465/ S467) Rabbit polyclonal IgG (3101), anti-SMAD2/3 Rabbit monoclonal IgG (8685), anti-c-Myc Rabbit monoclonal IgG (5605), anti-p27 KIP1 Rabbit monoclonal IgG (3688), anti-p21 ${ }^{\text {WAF1/CIP1 }}$ Rabbit monoclonal IgG (2947), anti-GAPDH Rabbit monoclonal IgG (used at 1:5000 dilution) (2118) and anti-SIK2 Rabbit IgG (6919) were all purchased from Cell Signalling Technology (CST). AntiPAI-1 Rabbit polyclonal IgG (ab66705), anti-CTGF Rabbit polyclonal IgG (ab6992) and anti-CRTC3 Rabbit monoclonal IgG (ab91654) were purchased from Abcam. AntiPhospho-CRTC3 (S370) Sheep polyclonal IgG (S253D, third bleed) and anti-SIK3 Sheep polyclonal IgG (S373D, third bleed) were generated by MRC PPU Reagents and Services. Species-specific horseradish peroxidase (HRP)conjugated secondary antibodies were used at 1:5000 dilution. Rabbit anti-Sheep polyclonal IgG $(\mathrm{H}+\mathrm{L}) \mathrm{Sec}-$ ondary Antibody, HRP (31480) and Goat anti-Mouse polyclonal IgG $(\mathrm{H}+\mathrm{L})$ Secondary Antibody, HRP (31430) were purchased from Thermo Fisher Scientific. Goat antiRabbit polyclonal IgG $(\mathrm{H}+\mathrm{L})$, HRP-conjugated Secondary Antibody (7074), was purchased from CST.

\section{Cytokines and pharmacological inhibitors}

Purified recombinant human TGF $\beta_{1}$ was purchased from either R\&D Systems or PeproTech, and reconstituted in sterile $4 \mathrm{mM} \mathrm{HCl}$ containing $1 \mathrm{mg} \mathrm{mL}^{-1}$ bovine serum albumin (BSA). Prior to stimulation with TGF $\beta_{1}$, cells were cultured in serum-free culture media for $\sim 16 \mathrm{~h}$ at $37^{\circ} \mathrm{C}$ in order to reduce autocrine signalling. Pharmacological inhibitors were reconstituted at $10 \mathrm{mM}$ in dimethyl sulfoxide (DMSO), and used at the concentrations and durations indicated in the respective figure/figure legend. For all inhibitor experiments, control cells were incubated with an equivalent volume of DMSO.

\section{Generation of SIK KI mice}

SIK2 ${ }^{\text {T175A }} /$ SIK $3^{\text {T163A }}$ homozygous kinase dead knock-in (KI) mice were bred from SIK2 $2^{\text {tm1.1Arte }}$ and SIK3 ${ }^{\text {tm1.1Arte }}$ mice maintained on a C57BL/6NJ genetic background as described previously ${ }^{39}$. Primary mouse embryonic 
fibroblasts (MEFs) were generated from SIK2 ${ }^{\mathrm{T} 175 \mathrm{~A}} /$ SIK3 $^{\text {T163A }}$ or SIK3 ${ }^{\text {WT }}$ embryos at E11.5-13.5 as detailed previously $^{62}$. Primary and SV-40-immortalised MEFs were cultured in DMEM supplemented with $20 \%(\mathrm{v} / \mathrm{v})$ FBS, $2 \mathrm{mM}$ L-glutamine, 100 units $\mathrm{mL}^{-1}$ penicillin, $100 \mu \mathrm{g} \mathrm{mL}^{-1}$ streptomycin, 1× Minimum Essential Medium (MEM) Non-Essential Amino Acids (NEAA) and $1 \mathrm{mM}$ sodium pyruvate. Mice were maintained in individually ventilated cages, and provided with free access to food and water under specific pathogen-free conditions consistent with E.U. and U.K. regulations. All animal breeding and studies were conducted following approval by the University of Dundee Ethical Review Committee, and performed under a U.K. Home Office Project Licence granted under the Animals (Scientific Procedures) Act 1986.

\section{Mammalian cell culture}

A-172 human glioblastoma, U2OS human osteosarcoma, HaCaT human immortalised keratinocyte, HEK293 human embryonic kidney and HeLa human cervical adenocarcinoma cells were obtained from the MRC PPU Tissue Culture facility, and cultured in Dulbecco's Modified Eagle's Medium (DMEM) supplemented with 10\% (v/v) foetal bovine serum (FBS), $2 \mathrm{mM}$ L-glutamine, 100 units $\mathrm{mL}^{-1}$ penicillin and $100 \mu \mathrm{g} \mathrm{mL}^{-1}$ streptomycin (hereafter referred to as D10F media). NMuMG murine mammary epithelial cells were cultured in D10F media supplemented with $10 \mu \mathrm{g} \mathrm{mL}^{-1}$ insulin (from bovine pancreas). All cell lines were maintained at $37^{\circ} \mathrm{C}$ in a humidified atmosphere with $5 \%(\mathrm{v} / \mathrm{v}) \mathrm{CO}_{2}$ levels, and routinely tested for mycoplasma contamination. Seeding cell densities for each cell line was optimised to ensure that stimulation of cells with ligands and small-molecule inhibitors, as well as cell lysis, was performed in subconfluent cultures.

\section{Generation of $\mathrm{SMAD3}^{-/-}$knockout cells using CRISPR-Cas9}

To generate $S M A D 3^{-/-}$knockout cells by CRISPR-Cas9 genome editing, $\mathrm{HaCaT}$ cells were transfected with the plasmid pSpCas9(BB)-2A-GFP (PX458) ${ }^{63}$ containing both the Cas9 endonuclease and a guide RNA (gRNA) pair targeting exon 6 of the endogenous SMAD3 gene. For the acquisition of single-cell knockout clones, single cells were isolated by fluorescence-activated cell sorting (FACS) and plated in individual wells of 96-well cell culture plates. Viable cell clones were expanded, and successful knockouts were confirmed by both Western immunoblotting and genomic DNA sequencing. Sequence of gRNA oligonucleotides: SMAD3 forward gRNA 5'-CACCGGAATGTCTCCCCGACGCG C-3'; SMAD3 reverse gRNA 5'-AAACGCGCGTCGG GGAGACATTCC-3'.

\section{Mammalian cell lysis}

Cells were washed twice with cold $1 \times$ DPBS and incubated with lysis buffer $(50 \mathrm{mM}$ Tris/HCl, $\mathrm{pH} 7.5,270 \mathrm{mM}$ sucrose, $150 \mathrm{mM}$ sodium chloride, $1 \mathrm{mM}$ EDTA, $\mathrm{pH}$ 8.0, $1 \mathrm{mM}$ EGTA, pH 8.0, $1 \mathrm{mM}$ sodium orthovanadate, $10 \mathrm{mM}$ sodium $\beta$-glycerophosphate, $50 \mathrm{mM}$ sodium fluoride, $5 \mathrm{mM}$ sodium pyrophosphate and $1 \%(\mathrm{v} / \mathrm{v})$ Nonidet P-40 (NP-40)) supplemented with Complete, EDTA-free Protease Inhibitors (Roche) (one tablet per $25 \mathrm{~mL}$ ) for $\sim 5 \mathrm{~min}$ on ice. Cell lysates were transferred to $1.5-\mathrm{mL}$ microcentrifuge tubes and centrifuged at $16,000 \times$ $g$ for $10 \mathrm{~min}$ at $4{ }^{\circ} \mathrm{C}$, and either processed immediately or cryopreserved in liquid nitrogen prior to storage at $-80^{\circ}$ C. The protein concentrations of the cell lysate samples were determined using Pierce Coomassie (Bradford) Protein Assay Kit (Thermo Fisher Scientific). Cell lysate samples were subsequently diluted using $4 \times$ NuPAGE LDS (lithium dodecyl sulfate) sample buffer (Invitrogen) supplemented with $8 \%(\mathrm{v} / \mathrm{v})$ 2-Mercaptoethanol (2-ME) (Sigma-Aldrich) and the sample concentrations equalised.

\section{SDS-PAGE and western blotting}

Cleared cell lysates (10-20 $\mu \mathrm{g}$ of protein) or immunoprecipitates were denatured by boiling for $5 \mathrm{~min}$ at $95^{\circ} \mathrm{C}$ and resolved by SDS-PAGE. The resolved proteins were electrophoretically transferred onto Amersham Protran $0.45-\mu \mathrm{m}$ nitrocellulose membranes (GE Healthcare Life Sciences). Membranes were blocked using 5\% (w/v) nonfat milk in Tris-buffered saline (TBS) $(50 \mathrm{mM}$ Tris- $\mathrm{HCl}$, $\mathrm{pH} 7.5,150 \mathrm{mM} \mathrm{NaCl}$ ) containing $0.1 \%(\mathrm{v} / \mathrm{v})$ TWEEN-20 (hereafter called TBST) for $1 \mathrm{~h}$ at RT on a bench-top platform rocker. The membranes were subsequently incubated with the appropriate primary antibodies (as detailed above) diluted in 5\% (w/v) milk-TBST overnight $(\sim 16 \mathrm{~h})$ at $4{ }^{\circ} \mathrm{C}$ with continuous agitation. Following this, membranes were washed three times for $5 \mathrm{~min}$ using TBST prior to incubation with the relevant speciesspecific horseradish peroxidase (HRP)-conjugated secondary antibodies, also diluted in 5\% (w/v) milk-TBST for $1 \mathrm{~h}$ at RT on a bench-top platform rocker. The membranes were subsequently washed three times for $5 \mathrm{~min}$ using TBST prior to enhanced chemiluminescence detection, and exposed onto Medical X-Ray Film (Konica Minolta) or Amersham Hyperfilm ECL (GE Healthcare Life Sciences) under safelight conditions. The films were developed using an SRX-101A automated medical film processor (Konica Minolta).

\section{Luciferase transcriptional reporter assay}

U2OS 2G transcriptional reporter cells were seeded in six-well cell culture plates, and incubated with the required small-molecule inhibitors/cytokines at the indicated concentrations and duration. Cells were 
subsequently washed twice with $1 \times$ DPBS, and lysed using $1 \times$ Cell Culture Lysis Reagent (CCLR, Promega). Cell culture plates were incubated for $\sim 5 \mathrm{~min}$ on a bench-top platform rocker to ensure efficient cell lysis. Cell lysates were transferred to $1.5-\mathrm{mL}$ microcentrifuge tubes and kept on ice. Lysate samples were vortexed for $\sim 10 \mathrm{~s}$, centrifuged at $12,000 \times g$ for $2 \mathrm{~min}$ at $4{ }^{\circ} \mathrm{C}$ and $200 \mu \mathrm{L}$ of supernatant was transferred to new $1.5-\mathrm{mL}$ microcentrifuge tubes. Lysate samples were subsequently transferred to 96-well white flat-bottom cell culture microplates. An equivalent volume of $2 \times$ Luciferase Assay Buffer (50 mM Tris/Phosphate, $\mathrm{pH} 7.8,16 \mathrm{mM} \mathrm{MgCl}_{2}$, $2 \mathrm{mM}$ dithiothreitol (DTT), $1 \mathrm{mM}$ adenosine triphosphate (ATP), 30\% (v/v) glycerol, 1\% (w/v) bovine serum albumin (BSA), $250 \mu \mathrm{M}$ D-luciferin and $8 \mu \mathrm{M}$ sodium pyrophosphate) was subsequently added to each well, and the microplate incubated for $\sim 1 \mathrm{~min}$ on a bench-top vibrating platform. Luminescence values were obtained using an EnVision 2104 Multimode Microplate Reader (PerkinElmer). The protein concentrations of each lysate sample were determined using Pierce Coomassie (Bradford) Protein Assay Kit (Thermo Fisher Scientific) and used to normalise luminescence values.

\section{Cellular fractionation}

Extraction of separate cytoplasmic and nuclear protein fractions from cultured U2OS cells was performed using NE-PER Nuclear and Cytoplasmic Extraction Reagents (Thermo Fisher Scientific) according to the manufacturer's protocol. The supplied lysis buffers (CER I and NER) were supplemented with $1 \times$ Complete, EDTA-free Protease Inhibitors (Roche) immediately prior to use. Subcellular fractions were reduced using NuPAGE $4 \times$ LDS sample buffer containing $8 \%$ (v/v) 2-mercaptoethanol, and incubated at $95^{\circ} \mathrm{C}$ for $5 \mathrm{~min}$ prior to SDS-PAGE. Fractions were resolved by SDS-PAGE and analysed via Western immunoblotting.

\section{Quantitative reverse transcription polymerase chain reaction}

For all reverse transcription polymerase chain reaction (RT-qPCR) experiments, cells were seeded in six-well cell culture plates and incubated with the required TGF $\beta_{1} /$ inhibitor combinations for the durations indicated in the respective figure legends. Total RNA was isolated from the cells using the RNeasy Micro Kit (Qiagen) according to the manufacturer's protocol. Complementary DNA (cDNA) was synthesised from 0.5 to $1.0 \mu \mathrm{g}$ of isolated RNA using iScript cDNA Synthesis Kit (Bio-Rad) according to the manufacturer's protocol. All RT-qPCR reactions were conducted in triplicate, and included 50\% (v/v) SsoFast EvaGreen Supermix (Bio-Rad), $0.5 \mu \mathrm{M}$ forward primer, $0.5 \mu \mathrm{M}$ reverse primer and the required volume of cDNA. RT-qPCR experiments were performed using CFX96 or CFX384 Real-Time PCR Detection Systems (Bio-Rad). The Ct (cycle threshold) values for each gene of interest were normalised to the arithmetic mean $\mathrm{Ct}$ value of the reference gene glyceraldehyde-3phosphate dehydrogenase (GAPDH) or $18 \mathrm{~S}$ ribosomal RNA (rRNA) using Microsoft Excel software. The $2^{-\Delta \Delta C t}$ relative quantification method was then used to analyse the relative changes in gene expression between control and treatment conditions ${ }^{64}$. GraphPad Prism software (version 8.0) was used to generate graphs and perform statistical analysis.

\section{Immunofluorescence microscopy}

U2OS GFP-SMAD2 cells were plated onto glass coverslips and treated as described in the respective figure legends. Cells were fixed in $4 \%(\mathrm{v} / \mathrm{v})$ paraformaldehyde (PFA) immediately after aspirating culture media for $15 \mathrm{~min}$ at RT before washing twice in $1 \times$ PBS. Permeabilisation was performed using $0.2 \%$ Triton X (Sigma) in PBS for $10 \mathrm{~min}$ at RT before washing twice more in $1 \times$ PBS and blocking for $1 \mathrm{~h}$ at RT with 5\% (w/v) BSA in PBS. Primary antibody (anti-GFP polyclonal IgG, 1:1000 dilution) in $0.5 \%$ BSA $/ 0.2 \%$ TWEEN-20 (Sigma)/PBS was added to coverslips for $1 \mathrm{~h}$ at $37^{\circ} \mathrm{C}$ before washing three times in $0.5 \%$ BSA/0.2\% TWEEN-20/PBS (10 min per wash). Cells were incubated with the secondary AlexaFluor-conjugated antibody (anti-Rabbit, $488 \mathrm{~nm}, 1: 500$ dilution) for $1 \mathrm{~h}$ at RT, before washing with $0.5 \% \mathrm{BSA} /$ $0.2 \%$ TWEEN-20/PBS three times (20 min per wash). During the second wash, 4',6-Diamidino-2-Phenylindole Dihydrochloride (DAPI, Sigma) was added at a final concentration of $1 \mu \mathrm{g} \mathrm{mL}^{-1}$ and removed in the final wash. Coverslips were rinsed in deionised $\mathrm{H}_{2} \mathrm{O}$ and mounted onto glass microscopy slides using VECTASHIELD (Vector Laboratories). Coverslips were sealed and left to dry overnight at $4{ }^{\circ} \mathrm{C}$. Cells were imaged using the DeltaVision Imaging System $(20 \times$ or $60 \times$ objective, GE Healthcare), and processed using softWoRx (GE Healthcare) and OMERO ${ }^{65}$.

\section{Annexin $\mathrm{V}$ staining assay}

NMuMG cells were incubated with the required cytokine/inhibitor combinations. Following this, both adherent and non-adherent (i.e. apoptotic) cells were collected into 50-mL conical centrifuge tubes, pelleted by centrifugation $(300 \times g, 2 \mathrm{~min})$ and washed once using cold $1 \times$ DPBS. Cells were subsequently centrifuged $(300 \times g$, $2 \mathrm{~min}$ ); the cell pellets were resuspended in Annexin Binding Buffer, ABB (10 mM HEPES, $140 \mathrm{mM} \mathrm{NaCl}$ and $2.5 \mathrm{mM} \mathrm{CaCl}_{2}, \mathrm{pH} 7.4$ ), and transferred to $1.5-\mathrm{mL}$ microcentrifuge tubes. The required cell suspension samples were then incubated with Annexin V, AlexaFluor 488 conjugate (Invitrogen, A13201) for $15 \mathrm{~min}$ at RT and protected from light. The appropriate samples 
were subsequently incubated with $5 \mu \mathrm{g} \mathrm{mL} \mathrm{L}^{-1}$ DAPI $\left(4^{\prime}, 6-\right.$ diamidino-2-phenylindole) (Invitrogen). Samples were immediately analysed using a BD LSRFortessa Cell Analyser (BD Biosciences) and BD FACSDiva acquisition software (BD Biosciences). Annexin V Alexa-Fluor 488 fluorescence was detected by excitation at $488 \mathrm{~nm}$ and emission at $530 \pm 30 \mathrm{~nm}$, and DAPI fluorescence was detected by excitation at $355 \mathrm{~nm}$ and emission at $450 \pm$ $50 \mathrm{~nm}$. Single cells were identified on the basis of forward light scatter (FSC) and side light scatter (SSC), and subsequently evaluated for Annexin V Alexa-Fluor 488 and DAPI fluorescence. Data analysis was performed using FlowJo Single Cell Analysis Software (BD Biosciences).

\section{Cellular proliferation}

$\mathrm{HaCaT}$ cells were assayed for proliferation using an IncuCyte ZOOM Live-Cell Analysis System (Sartorius). Cells were plated in 96-well cell culture plates $\left(1 \times 10^{3}\right.$ cells per well, 6 wells per condition, plates in triplicate) and incubated with the required small-molecule inhibitor in the presence or absence of recombinant human TGF $\beta_{1}$ $\left(5 \mathrm{ng} \mathrm{mL}^{-1}\right)$. Cells were imaged every $2 \mathrm{~h}$ over a period of $170 \mathrm{~h}$, and the percent confluence determined using IncuCyte ZOOM Analysis Software (Sartorius).

\section{Crystal violet cellular viability assay}

NMuMG cells were seeded in 96-well cell culture plates and incubated for $24 \mathrm{~h}$ at $37^{\circ} \mathrm{C}$ to enable adherence of cells to culture plates. The inclusion of wells containing culture medium without cells were used as negative control wells. Following the initial $24 \mathrm{~h}$ incubation, culture media was aspirated and replaced with reduced serum (1\% v/v FBS) DMEM supplemented with $10 \mu \mathrm{g} \mathrm{mL}^{-1}$ bovine insulin (Sigma-Aldrich) containing the required inhibitors or equivalent volume of DMSO, with or without recombinant human $\operatorname{TGF}_{1}\left(5 \mathrm{ng} \mathrm{mL}^{-1}\right)$, and incubated for a further $24 \mathrm{~h}$. Cells were subsequently fixed using $10 \%(\mathrm{v} / \mathrm{v})$ methanol/10\% (v/v) acetic acid for $5 \mathrm{~min}$ at RT, and washed with $1 \times$ PBS. Fixed cells were stained using $0.5 \%(\mathrm{w} / \mathrm{v})$ crystal violet staining solution ( $0.5 \mathrm{~g}$ of crystal violet powder (Sigma-Aldrich), $80 \mathrm{~mL}$ of distilled $\mathrm{H}_{2} \mathrm{O}$ and $20 \mathrm{~mL}$ of methanol) for $20 \mathrm{~min}$ at RT on a bench-top platform rocker. Plates were subsequently washed carefully using tap water, inverted on filter paper to remove residual liquid and allowed to air-dry overnight. Following this, methanol was added to each well and incubated for $20 \mathrm{~min}$ at RT on a bench-top platform rocker. The absorbance value of each well was measured at $570 \mathrm{~nm}\left(\mathrm{OD}_{570}\right)$ using a 96-well microplate spectrophotometer. The mean $\mathrm{OD}_{570}$ value of negative control wells (i.e. wells not containing cells) was subtracted from the values obtained from each well on the culture plate, and the percentage of viable cells for each condition determined relative to the mean average $\mathrm{OD}_{570}$ value of non-stimulated DMSO control-treated cells.

\section{In vitro protein kinase assay}

In all, $21-\mu \mathrm{L}$ reaction solutions were prepared containing $200 \mathrm{ng}$ of protein kinase and $2 \mu \mathrm{g}$ of substrate protein in $1 \times$ kinase assay buffer $(50 \mathrm{mM}$ Tris- $\mathrm{HCl}, \mathrm{pH} 7.5$, $0.1 \mathrm{mM}$ EGTA, $10 \mathrm{mM}$ magnesium acetate, $0.1 \%(\mathrm{v} / \mathrm{v}) 2$ mercaptoethanol and $\left.0.1 \mathrm{mM}\left[\gamma^{32} \mathrm{P}\right]-\mathrm{ATP}\right)$. Reactions were conducted at $30^{\circ} \mathrm{C}$ for $30 \mathrm{~min}$ at $1050 \mathrm{rpm}$ and terminated via the addition of $7 \mu \mathrm{L}$ of NuPAGE $4 \times$ LDS sample buffer containing $8 \%(\mathrm{v} / \mathrm{v}) 2$-mercaptoethanol. For in vitro kinase assays involving the use of small-molecule inhibitors, reaction solutions containing all the required components were incubated at $30^{\circ} \mathrm{C}$ for $10 \mathrm{~min}$ at $1050 \mathrm{rpm}$ prior to the addition of $0.1 \mathrm{mM}\left[\gamma^{32} \mathrm{P}\right]$-ATP. Reactions were then performed as detailed previously. Samples were incubated at $95^{\circ} \mathrm{C}$ for $5 \mathrm{~min}$, and subsequently centrifuged at $5.0 \times 10^{3} \times g$ for $1 \mathrm{~min}$. Samples were loaded onto NuPAGE $4-12 \%$ Bis-Tris precast polyacrylamide gels and resolved via SDS-PAGE. Polyacrylamide gels were subsequently stained with InstantBlue Coomassie Protein Stain (Expedeon) to visualise the resolved recombinant proteins, and imaged using the ChemiDoc Imaging System (Bio-Rad). ${ }^{32} \mathrm{P}$ radioactivity was analysed via autoradiography using Amersham Hyperfilm (GE Healthcare Life Sciences).

\section{Statistical analysis}

All experiments have a minimum of three biological replicates, unless otherwise stated in the respective figure legend. In addition, all luciferase, RT-qPCR, cellular proliferation, annexin $\mathrm{V}$ staining and crystal violet staining experiments have at least three technical repeats for each biological replicate. The data are presented as the arithmetic mean, with error bars denoting the standard error of the mean (SEM). The statistical significance of differences between experimental conditions was assessed by using either Student's $t$ test or analysis of variance (ANOVA) with Bonferroni correction using GraphPad Prism (version 8.0) analysis software. Differences in the mean of experimental conditions were considered significant if the probability value ( $p$-value) was $<0.05$. All immunoblotting figures are representative.

\footnotetext{
Acknowledgements

We thank the staff at the MRC PPU International Centre for Kinase Profiling (University of Dundee, UK) for providing us with the inhibitor panel used for screening. We thank E. Allen, J. Stark and A. Muir for their help and assistance with tissue culture, and the cloning, antibody and protein production teams within MRC PPU Reagents and Services (University of Dundee, UK), coordinated by J. Hastie and H. McLauchlan. We thank Dr. R. Clarke from the flow cytometry facility (School of Life Sciences, University of Dundee, UK) for her invaluable help and advice with Annexin $\mathrm{V}$ staining assays. LDH is supported by the UK Medical Research Council (MRC) PhD studentship. NJD is supported by the UK MRC grant awarded to PC. GPS is supported by the U.K. MRC (Grant MC_UU_12016/3) and the pharmaceutical companies supporting the Division of Signal Transduction Therapy (Boehringer-Ingelheim, GlaxoSmithKline, Merck-Serono).
} 


\section{Author details}

${ }^{1}$ MRC Protein Phosphorylation and Ubiquitylation Unit, School of Life Sciences, University of Dundee, Sir James Black Centre, Dow Street, Dundee DD1 5EH, UK. ${ }^{2}$ The Francis Crick Institute, 1 Midland Road, London NW1 1AT, UK. ${ }^{3}$ Present address: Cancer Research UK Beatson Institute, Switchback Road, Bearsden, Glasgow G61 1BD, UK. ${ }^{4}$ Present address: The Institute of Cancer Research, 15 Cotswold Road, Sutton, London SM2 5NG, UK

\section{Conflict of interest}

The authors declare that they have no conflict of interest.

\section{Publisher's note}

Springer Nature remains neutral with regard to jurisdictional claims in published maps and institutional affiliations.

Supplementary Information accompanies this paper at (https://doi.org/ 10.1038/s41419-020-2241-6).

Received: 1 October 2019 Revised: 8 January 2020 Accepted: 8 January 2020

Published online: 22 January 2020

\section{References}

1. Siegel, P. M. \& Massagué, J. Cytostatic and apoptotic actions of TGF- $\beta$ in homeostasis and cancer. Nat. Rev. Cancer 3, 807-820 (2003).

2. Xu, J., Lamouille, S. \& Derynck, R. TGF-ß-induced epithelial to mesenchymal transition. Cell Res. 19, 156-172 (2009).

3. David, C. J. \& Massagué, J. Contextual determinants of TGF $\beta$ action in development, immunity and cancer. Nat. Rev. Mol. Cell Biol. 19, 419-435 (2018).

4. Zhang, Y., Alexander, P. B. \& Wang, X.F. TGF- $\beta$ family signaling in the control of cell proliferation and survival. Cold Spring Harb. Perspect. Biol. 9, a022145 (2017).

5. Li, M. O. \& Flavell, R. A. TGF-B: a master of all T cell trades. Cell 134, 392-404 (2008).

6. Massagué, J. TGFß signalling in context. Nat. Rev. Mol. Cell Biol. 13, 616-630 (2012).

7. Massagué, J. TGFß in cancer. Cancer Cell 134, 215-230 (2008).

8. Ikushima, H. \& Miyazono, K. TGF $\beta$ signalling: a complex web in cancer progression. Nat. Rev. Cancer 10, 415-424 (2010).

9. Drabsch, Y. \& ten Dijke, P. TGF- $\beta$ signalling and its role in cancer progression and metastasis. Cancer Metastasis Rev. 31, 553-568 (2012).

10. Bierie, B. \& Moses, H. L. TGFß: the molecular Jekyll and Hyde of cancer. Nat. Rev. Cancer 6, 506-520 (2006).

11. Inman, G. J. Switching TGF $\beta$ from a tumor suppressor to a tumor promoter Curr. Opin. Genet. Dev. 21, 93-99 (2011).

12. Akhurst, R. J. \& Hata, A. Targeting the TGFß signalling pathway in disease. Nat Rev. Drug Discov. 11, 790-811 (2012).

13. Akhurst, R. J. Targeting TGF- $\beta$ signaling for therapeutic gain. Cold Spring Harb. Perspect. Biol. 9, a022301 (2017).

14. Connolly, E. C., Freimuth, J. \& Akhurst, R. J. Complexities of TGF- $\beta$ targeted cancer therapy. Int. J. Biol. Sci. 8, 964-978 (2012).

15. Wrana, J. L., Attisano, L., Wieser, R., Ventura, F. \& Massagué, J. Mechanism of activation of the TGF- $\beta$ receptor. Nature 370, 341-347 (1994).

16. Zhang, Y., Feng, X.-H., Wu, R.-Y. \& Derynck, R. Receptor-associated Mad homologues synergize as effectors of the TGF- $\beta$ response. Nature $\mathbf{3 8 3}$ 168-172 (1996).

17. Massaous, J. \& Hata, A. TGF- $\beta$ signalling through the Smad pathway. Trends Cell Biol. 7, 187-192 (1997)

18. Massagué, J., Seoane, J. \& Wotton, D. Smad transcription factors. Genes Dev. 19 2783-2810 (2005)

19. Shi, Y. \& Massagué, J. Mechanisms of TGF- $\beta$ signaling from cell membrane to the nucleus. Cell 113, 685-700 (2003)

20. Hill, C. S. Transcriptional control by the SMADs. Cold Spring Harb. Perspect. Biol. 8, a022079 (2016).

21. Rojas-Fernandez, A. et al. Rapid generation of endogenously driven transcriptional reporters in cells through CRISPR/Cas9. Sci. Rep. 5, 9811 (2015).
22. Keeton, M. R., Curriden, S. A., van Zonneveld, A. J. \& Loskutoff, D. J. Identification of regulatory sequences in the type 1 plasminogen activator inhibitor gene responsive to transforming growth factor beta. J. Biol. Chem. 266, 23048-23052 (1991)

23. Dennler, S. et al. Direct binding of Smad3 and Smad4 to critical TGF betainducible elements in the promoter of human plasminogen activator inhibitor-type 1 gene. EMBO J. 17, 3091-3100 (1998).

24. Abe, M. et al. An assay for transforming growth factor- $\beta$ using cells transfected with a plasminogen activator inhibitor-1 promoter-luciferase construct. Anal. Biochem. 216, 276-284 (1994).

25. Bright, N. J., Thornton, C. \& Carling, D. The regulation and function of mammalian AMPK-related kinases. Acta Physiol. 196, 15-26 (2009).

26. Shackelford, D. B. \& Shaw, R. J. The LKB1-AMPK pathway: metabolism and growth control in tumour suppression. Nat. Rev. Cancer 9, 563-575 (2009).

27. DaCosta Byfield, S., Major, C., Laping, N. J. \& Roberts, A. B. SB-505124 is a selective inhibitor of transforming growth factor-beta type I receptors ALK4, ALK5, and ALK7. Mol. Pharmacol. 65, 744-752 (2004).

28. Vogt, J., Traynor, R. \& Sapkota, G. P. The specificities of small molecule inhibitors of the TGFß and BMP pathways. Cell. Signal. 23, 1831-1842 (2011).

29. Tojo, $M$. et al. The ALK-5 inhibitor A-83-01 inhibits Smad signaling and epithelial-to-mesenchymal transition by transforming growth factor-beta. Cancer Sci. 96, 791-800 (2005).

30. Callahan, J. F. et al. Identification of novel inhibitors of the transforming growth factor beta1 (TGF-beta1) type 1 receptor (ALK5). J. Med. Chem. 45, 999-1001 (2002).

31. Rena, G., Bain, J., Elliott, M. \& Cohen, P. D4476, a cell-permeant inhibitor of CK1 suppresses the site-specific phosphorylation and nuclear exclusion of FOXO1a. EMBO Rep. 5, 60-65 (2004).

32. Cuny, G. D. et al. Structure-activity relationship study of bone morphogenetic protein (BMP) signaling inhibitors. Bioorg. Med. Chem. Lett. 18, 4388-4392 (2008).

33. Clark, K. et al. Phosphorylation of CRTC3 by the salt-inducible kinases controls the interconversion of classically activated and regulatory macrophages. Proc Natl Acad. Sci. USA 109, 16986-16991 (2012).

34. Altarejos, J. Y. \& Montminy, M. CREB and the CRTC co-activators: sensors for hormonal and metabolic signals. Nat. Rev. Mol. Cell Biol. 12, 141-151 (2011).

35. Sonntag, T. et al. Analysis of a CAMP regulated coactivator family reveals an alternative phosphorylation motif for AMPK family members. PLOS ONE 12, e0173013 (2017).

36. Hawley, S. A. et al. Complexes between the LKB1 tumor suppressor, STRADa/ $\beta$ and $\mathrm{MO} 25 \mathrm{\alpha} / \mathrm{B}$ are upstream kinases in the AMP-activated protein kinase cascade. J. Biol. 2, 28 (2003).

37. Woods, A. et al. LKB1 is the upstream kinase in the AMP-activated protein kinase cascade. Curr. Biol. 13, 2004-2008 (2003).

38. Lizcano, J. M. et al. LKB1 is a master kinase that activates 13 kinases of the AMPK subfamily, including MARK/PAR-1. EMBO J. 23, 833-843 (2004).

39. Darling, N. J., Toth, R., Simon, J., Arthur, C. \& Clark, K. Inhibition of SIK2 and SIK3 during differentiation enhances the anti-inflammatory phenotype of macrophages. Biochem J 474, 521-537 (2017).

40. Brown, K. A. et al. Induction by transforming growth factor- $\beta 1$ of epithelial to mesenchymal transition is a rare event in vitro. Breast Cancer Res. 6, R215-R231 (2004).

41. Ozdamar, B. et al. Regulation of the polarity protein Par6 by TGFbeta receptors controls epithelial cell plasticity. Science 307, 1603-1609 (2005).

42. Ramjaun, A. R., Tomlinson, S., Eddaoudi, A. \& Downward, J. Upregulation of two BH3-only proteins, Bmf and Bim, during TGF $\beta$-induced apoptosis. Oncogene 26, 970-981 (2007).

43. Avery-Cooper, G. et al. Par6 is an essential mediator of apoptotic response to transforming growth factor beta in NMuMG immortalized mammary cells. Cancer Cell Int. 14, 19 (2014).

44. Liu, Y. et al. YAP modulates TGF- $\beta 1$-induced simultaneous apoptosis and EMT through upregulation of the EGF receptor. Sci. Rep. 7, 45523 (2017).

45. Ozanne, J., Prescott, A. R. \& Clark, K. The clinically approved drugs dasatinib and bosutinib induce anti-inflammatory macrophages by inhibiting the saltinducible kinases. Biochem. J. 465, 271-279 (2015)

46. Sundberg, T. B et al. Small-molecule screening identifies inhibition of saltinducible kinases as a therapeutic strategy to enhance immunoregulatory functions of dendritic cells. Proc. Natl Acad. Sci. USA 111, 12468-12473 (2014).

47. Keating, G. M. Dasatinib: a review in chronic myeloid leukaemia and Ph+ acute lymphoblastic leukaemia. Drugs 77, 85-96 (2017). 
48. Rosti, G., Castagnetti, F., Gugliotta, G. \& Baccarani, M. Tyrosine kinase inhibitors in chronic myeloid leukaemia: which, when, for whom? Nat. Rev. Clin. Oncol. 14, 141-154 (2017).

49. Datta, P. K., Blake, M. C. \& Moses, H. L. Regulation of plasminogen activator inhibitor-1 expression by transforming growth factor-beta -induced physical and functional interactions between smads and Sp1. J. Biol. Chem. 275, 40014-40019 (2000).

50. Binder, B. R. et al. Plasminogen activator inhibitor 1: physiological and pathophysiological roles. Physiology 17, 56-61 (2002).

51. Kowanetz, M. et al. TGFbeta induces SIK to negatively regulate type I receptor kinase signaling. J. Cell Biol. 182, 655-662 (2008).

52. Lönn, P. et al. Transcriptional induction of salt-inducible kinase 1 by transforming growth factor $\beta$ leads to negative regulation of type I receptor signaling in cooperation with the Smurf2 ubiquitin ligase. J. Biol. Chem. 287 12867-12878 (2012)

53. Yang, Y., Pan, X., Lei, W., Wang, J. \& Song, J. Transforming growth factor- $\beta 1$ induces epithelial-to-mesenchymal transition and apoptosis via a cell cycledependent mechanism. Oncogene 25, 7235-7244 (2006).

54. Song, J. EMT or apoptosis: a decision for TGF- $\beta$. Cell Res. 17, $289-290$ (2007)

55. Inman, G. J. \& Allday, M. J. Apoptosis induced by TGF-beta 1 in Burkitt's lymphoma cells is caspase 8 dependent but is death receptor independent. J. Immunol. 165, 2500-2510 (2000).

56. Spender, L. C. et al. TGF-beta induces apoptosis in human B cells by transcriptional regulation of BIK and BCL-XL. Cell Death Differ. 16, 593-602 (2009).

57. Spender, L. C. et al. Transforming growth factor- $\beta$ directly induces p53-upregulated modulator of apoptosis (PUMA) during the rapid induction of apoptosis in myc-driven B-cell lymphomas. J. Biol. Chem. 288, 5198-5209 (2013).

58. Kim, B.-C., Mamura, M., Choi, K. S., Calabretta, B. \& Kim, S.-J. Transforming growth factor beta 1 induces apoptosis through cleavage of BAD in a Smad3dependent mechanism in FaO hepatoma cells. Mol. Cell. Biol. 22, 1369-1378 (2002).

59. Hsing, A. Y., Kadomatsu, K., Bonham, M. J. \& Danielpour, D. Regulation of apoptosis induced by transforming growth factor-beta1 in nontumorigenic and tumorigenic prostatic epithelial cell lines. Cancer Res. 56, 5146-5149 (1996).

60. Edlund, S. et al. Transforming growth factor- $\beta 1$ (TGF- $\beta$ )-induced apoptosis of prostate cancer cells involves Smad7-dependent activation of p38 by TGFB-activated kinase 1 and mitogen-activated protein kinase kinase 3. Mol. Biol. Cell 14, 529-544 (2003).

61. Lin, P. H. et al. Overexpression of Bax sensitizes prostate cancer cells to TGFbeta induced apoptosis. Cell Res. 15, 160-166 (2005).

62. Strickson, S. et al. Roles of the TRAF6 and Pellino E3 ligases in MyD88 and RANKL signaling. Proc. Natl Acad. Sci. USA 114, E3481-E3489 (2017).

63. Ran, F. A. et al. Genome engineering using the CRISPR-Cas9 system. Nat Protoc. 8, 2281-2308 (2013).

64. Livak, K. J. \& Schmittgen, T. D. Analysis of relative gene expression data using real-time quantitative $P C R$ and the 2- $\triangle \triangle C T$ method. Methods 25, 402-408 (2001).

65. Allan, C. et al. OMERO: flexible, model-driven data management for experimental biology. Nat. Methods 9, 245-253 (2012) 